\title{
SECTION 67 OF THE \\ RESPONSIBLE ENERGY DEVELOPMENT ACT: SEEKING A BALANCE BETWEEN INDEPENDENCE AND ACCOUNTABILITY
}

\author{
GIORILYN BRUNO*
}

In 2012, the Alberta Government introduced Bill 2, the Responsible Energy Development Act, to replace the Energy Resource Conservation Board and to establish a single energy regulator. Among the most controversial aspects of this Act is section 67, which allows the Minister to give mandatory directions to the regulator. This article looks at the implications of that provision including its effect on board independence, board accountability, and the democratic process as a whole. After evaluating the case law, exploring issues of statutory interpretation, and comparing section 67 with similar provisions in Ontario and British Columbia, the author concludes that section 67 leaves open significant questions about the scope, legal status, and procedural requirements of directives issued under section 67.
En 2012, le gouvernement de l'Alberta présenta un projet de loi 2 intitulé Responsible Energy Development Act (Loi sur le développement responsable de l'énergie) pour remplacer le Energy Resource Conservation Board (Conseil pour la conservation de l'énergie) et pour créer un seul organisme de réglementation énergétique. La clause 67 représente un des aspects les plus controversés de cette Loi, en ce sens qu'elle permet au ministre de donner des instructions obligatoires à l'organisme de réglementation. Cet article examine les implications de cette disposition incluant son effet sur l'indépendance $d u$ Conseil, sa responsabilité et le processus démocratique dans son ensemble. Après avoir étudié la jurisprudence, examiné les questions d'interprétation des lois et avoir comparé la clause 67 aux dispositions semblables des lois en Ontario et en Colombie-Britannique, l'auteur conclut que la clause 67 laisse sans réponse d'importantes questions sur la portée, la capacité juridique et les modalités d'applications des directives émises en vertu de ladite clause.

\section{TABLE OF CONTENTS}

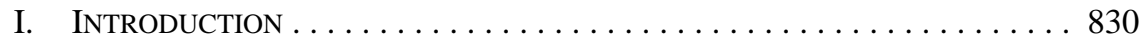

II. ACCOUNTABILITY AND Ministerial DiRECTIONS . . . . . . . . . . . 832

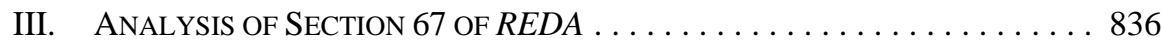

A. TeXt of Section $67 \ldots \ldots \ldots \ldots \ldots \ldots \ldots \ldots \ldots \ldots$

B. Who May ISSUE DiRections UndeR

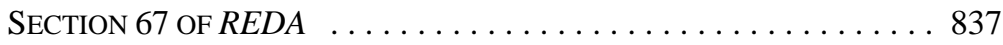

C. Purposes Under Section of 67 REDA . . . . . . . . . . . 837

D. THE LEGAL STATUS OF A DiRECTION ISSUED

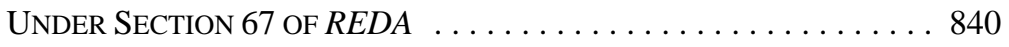

E. POLICY DiRECTIONS IN RELATION TO THE
AdJUdicAtive FUNCTION OF THE REGULATOR $\ldots \ldots \ldots \ldots \ldots .845$

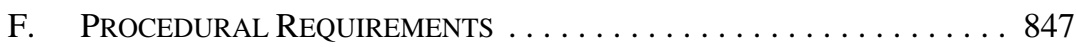

Research Fellow, Canadian Institute of Resources Law, Faculty of Law, University of Calgary, gbruno@ucalgary.ca. I would like to thank Professor Nigel Bankes for supervising this article and providing feedback throughout its development. I would also like to thank Professor Alastair Lucas, Professor Shaun Fluker, Jim Dilay, and Rob McManus for their insightful comments and suggestions, and the Alberta Law Review Editorial Board for its assistance in getting the article ready for publication. Lastly, I am grateful for the generous funding of the Alberta Law Foundation to the Canadian Institute of Resources Law which made this research possible. 


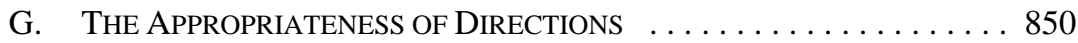

H. The Aboriginal Consultation Direction . . . . . . . . . . . 853

VI. A COMPARATIVE ANALYSIS WITH THE BC OIL AND GAS

COMMISSION, THE BC UTILITIES COMMISSION,

AND THE ONTARIO ENERGY BOARD . . . . . . . . . . . . . . . . . . 857

A. The BC OIL AND GAs COMMISSION . . . . . . . . . . . . . . . 857

B. The BC Utilities Commission $\ldots \ldots \ldots \ldots \ldots \ldots \ldots$. . . . . . 859

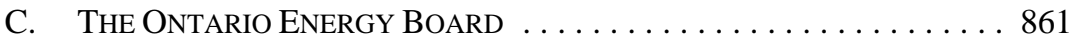

D. TABLE OF RESULTS . . . . . . . . . . . . . . . . . . . . . . . . 864

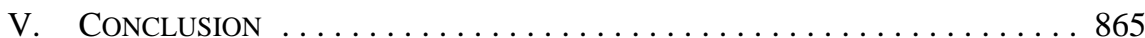

\section{INTRODUCTION}

In response to complaints of inconsistency and complexity in the legislative scheme for reviewing and approving energy development projects in Alberta, the provincial government in 2010 launched a broad initiative to enhance Alberta's competitiveness in attracting energy investments. ${ }^{1}$ After commissioning research studies, the Task Force established by the Alberta Government released a technical report in December 2010 observing that “Alberta's regulatory system is complex, lacking integrated policy or policy development, and involving multiple regulators with largely uncoordinated delivery."2 In particular, the Task Force noted that multiple ministries and agencies were involved in various aspects of upstream oil and gas development and at various points in the project lifecycle. ${ }^{3}$ To improve the system, the Task Force provided several recommendations including the creation of a single energy regulatory body. ${ }^{4}$

In the system envisioned by the Task Force, a single regulator would offer one point of contact for industry and other stakeholders, streamline the process for project proponents, and thus encourage investment in the province's resources. ${ }^{5}$ Furthermore, the Task Force observed that a single regulator might be a better fit for the province's recent attempts to achieve a broader integrated management system able to address the cumulative impacts of natural resource developments. ${ }^{6}$

The Alberta Government promptly implemented these recommendations starting with the single regulator. As a first step, it published Enhancing Assurance: Developing an Integrated

Alberta, Energizing Investment: A Framework to Improve Alberta's Natural Gas and Conventional Oil Competitiveness (Edmonton: Government of Alberta, 2010), online: <www.energy.alberta.ca/ Org/pdfs/EnergizingInvestment.pdf>.

2 Alberta, Regulatory Enhancement Project, Technical Report (Edmonton: Government of Alberta, 2010) at 2, online: <www.energy.alberta.ca/Org/pdfs/REPTechnicalReport.pdf> [Technical Report].

$3 \quad$ Ibid at 11 .

$4 \quad$ The six recommendations were to: (1) establish a new Policy Management Office and ensuring integration of natural resource policies; (2) create a single oil and gas regulatory body; (3) provide clear public engagement processes; (4) use a common approach to risk assessment and management; (5) adopt performance measures to enable continuous system improvement; and (6) enforce agreements where required. Ibid at 54-56.

$5 \quad$ Ibid at 57-58.

Ibid; Alberta, Land-Use Framework (Edmonton: Government of Alberta, 2008), online: <https://www. landuse.alberta.ca/LandUse\%20Documents/Land-use\%20Framework\%20-\%20 2008-12.pdf> [LUF]; Alberta Land Stewardship Act, SA 2009, c A-26.8 [ALSA]. 
Energy Resource Regulator in May 2011. ${ }^{7}$ In October 2012, it introduced Bill 2, the Responsible Energy Development Act, establishing the new Alberta Energy Regulator (AER).$^{8}$ In December 2012, REDA received Royal Assent and came into force in three different phases to ensure operational certainty during the transition. ${ }^{9}$ This transition is now complete and, as of 1 April 2014, the Regulator has full-lifecycle regulatory oversight of coal, oil sands, and oil and gas development in Alberta, from project application to abandonment and reclamation. The mandate of the Regulator is "to provide for the efficient, safe, orderly and environmentally responsible development of energy resources in Alberta.”10 The new Regulator is the successor to the Energy Resources Conservation Board, and assumes the regulatory functions of the Department of Environment and Sustainable Resource Development (ESRD) concerning energy projects, including granting permits, licences and approvals under the EPEA, ${ }^{11}$ the Public Lands Act, ${ }^{12}$ and the Water Act. ${ }^{13}$ Furthermore, the Regulator is responsible for upstream oil, gas, oil sands, and coal development under Part 8 of the Mines and Minerals Act. ${ }^{14}$

Amongst the most significant changes, the legislature included in REDA a provision, namely section 67, which allows the Minister to give mandatory directions to the new Regulator. ${ }^{15}$ While the power to issue directions may assure appropriate oversight and offer guidance within the broader policy framework of the Alberta Government, this type of provision may also cause difficulties concerning the ability of the Regulator to carry out its mandate with the required level of independence from the executive branch. ${ }^{16}$

This framework for energy projects established under the recent legislation is quite different from the previous system in which the ERCB had formal independence from the executive branch. ${ }^{17}$ Thus, a series of questions arise. To what extent will the Minister of

Alberta, Enhancing Assurance: Developing an Integrated Energy Resource Regulator (Edmonton: Government of Alberta, 2011), online: <www.energy.alberta.ca/Org/pdfs/REPEnhancingAssurance IntegratedRegulator. pdf $>$.

Responsible Energy Development Act, SA 2012, c R-17.3 [REDA].

$9 \quad$ Ibid. Phase 1 occurred in June 2013 when the REDA largely came into force and established the AER with a new mandate and governance structure. Phase II occurred in November 2013, when the AER assumed jurisdiction over Part 8 of the Mines and Minerals Act, RSA 2000, c M-17; the Public Lands Act, RSA 2000, c P-40; and the Private Surface Agreement Registry. Phase 3 occurred in Spring 2014 when the AER took on responsibility for the Water Act, RSA 2000, c W-3 and the Environmental Protection and Enhancement Act, RSA 2000, c E-12 [EPEA] in relation to energy projects.

REDA, supra note 8, s 2(1)(a).

Supra note 9.

Supra note 9.

The ERCB has been dissolved and the Energy Resources Conservation Act, RSA 2000, c E-10 as repealed by REDA, supra note 8, ss 2, 30-61, 81, 112. Water Act, supra note 9.

Mines and Minerals Act, supra note 9.

REDA, supra note 8, s 67.

Ibid, ss 3-4. See Alberta, Enhancing Assurance, Developing an Integrated Energy Regulator: Web Survey Feedback (Edmonton: Government of Alberta, 2011) at 8-9, online: <www.energy.alberta. ca/org/pdfs/2011REPWebResponses.pdf>; Shaun Fluker, "Bill 2 Responsible Energy Development Act: Setting the Stage for the Next 50 Years of Effective and Efficient Energy Resource Regulation and Development in Alberta” (8 November 2012), ABlawg (blog), online: <www.ablawg.ca/2012/11/08/ bill-2-responsible-energy-development-act-setting-the-stage-for-the-next-50-years-of-effective-andefficient-energy-resource-regulation-and-development-in-alberta $>$.

17 See ERCB Board Governance Charter, September 2011 at 3, online: <www.finance.alberta.ca/business/ agency-governance/agencies/B-I/ERCB-Mandate-and-Roles.pdf> (stating that the ERCB exercises its quasi-judicial and regulatory functions within the broader policy framework of the government of Alberta. While the Chair of the Board is accountable to the Alberta Legislature through the Minister of Energy for ensuring that the ERCB fulfills its legislative mandate, the ERCB maintains formal independence from the executive with respect to adjudicative and regulatory decision-making processes. Therefore, due to its independence from the government of Alberta and its specific expertise in the 
Energy or the Minister of Environment and Sustainable Resource Development interfere with the regulatory and adjudicative functions of the Regulator in order to set policies, priorities, and guidelines? Will the Ministers be able to interfere with the decision-making of the Regulator? How will the ministers communicate with the Regulator in a manner that ensures transparency?

This article analyzes the power of the Minister under section 67 of REDA, and attempts to determine how this power may be used and its implications. The article is structured as follows. Part II discusses the rationale for establishing independent or arm's length administrative agencies and analyzes the general advantages and drawbacks of ministerial directions. Part III analyzes section 67 of REDA and specifically addresses (i) who may issue directions, (ii) the purpose of a direction, (iii) the legal status of a direction issued under section 67 of REDA, (iv) whether the Minister may issue policy directions concerning the adjudicative functions of the Regulator, (v) the procedural requirements to issue a direction, (vi) the scope of section 67 of REDA, and (vii) the manner in which section 67 of $R E D A$ has currently been used. Part IV provides a comparative analysis, and discusses ministerial directions in the context of the BC Oil and Gas Commission, the BC Utilities Commission, and the Ontario Energy Board. Part V provides some concluding thoughts on the jurisdictional comparison and on the future of directions issued under section 67 of REDA.

\section{ACCOUNTABILITY AND MINISTERIAL DIRECTIONS}

Delegation of authority from a government to agencies, boards and commissions is a common feature of contemporary liberal democracies. ${ }^{18}$ These public bodies enjoy varying degrees of independence and exercise specialized public functions. ${ }^{19}$ However, they also add complexity to democratic government and have been referred to as "constitutional anomalies" since they are neither directly elected by constituents nor formally part of a governmental department, and have been created outside traditional structures to maintain some level of autonomy. ${ }^{20}$

regulation of oil and gas exploration and development, the courts recognize decisions of the ERCB as worthy of considerable judicial deference).

18 Ibid at 7. Several Directives of the European Union and their supporting Regulations emphasize the importance of independent regulators as essential in the goal of promoting competition and achieving full liberalization of electricity and gas markets. See EC, Commission Directive 2003/54/EC of 26 June 2003 concerning common rules for the internal market in electricity and repealing Directive 96/92/EC, [2003] OJ, L 176/37; EC, Commission Directive 2003/55/EC of 26 June 2003 concerning common rules for the internal market in natural gas and repealing Directive 98/30/EC, [2003] OJ, L 176/57; EC, Commission Regulation (EC) 1228/2003 of 26 June 2003 on conditions for access to the network for cross-border exchanges in electricity, [2003] OJ, L 176/1; EC, Commission Regulation (EC) 1229/2003 of 26 June 2003 laying down a series of guidelines for trans-European energy networks and repealing Decision No 1254/96/EC, [2003] OJ, L 176.

19 Alberta, Board Governance Review Task Force, At a Crossroads: The Report of the Board Governance Review Task Force, by Neil McCrank, Linda Hohol \& Allan Tupper (Edmonton: Board Governance Secretariat, 2007) at 7, online: <www.assembly.ab.ca/lao/library/egovdocs/2007/alz/162424.pdf>; Alberta, Public Agencies Governance Framework (Edmonton: Agency Government Secretariat, 2008) at 7, online: <alberta.ca/albertacode/images/ags-2008-02-Public-Agencies-Governance-Framework. pdf $>$.

20 See Anders Larsen et al, “Independent Regulatory Authorities in European Electricity Markets” (2006) 34 Energy Policy 2858 at 2859-60; Public Agencies Governance Framework, supra note 19 at 6; Lorne Sossin "The Puzzle of Independence for Administrative Bodies" at 9 online: <www.law.yale.edu/ documents/pdf/CompAdminLaw/Lorne_Sossin_CompAdLaw_paper.pdf>; McCrank, Hohol \& Tupper, ibid at 21 . 
There are no universal criteria to determine when it is appropriate to delegate authority to administrative agencies. The literature identifies four main reasons. First, a government may decide to delegate decision-making to technical experts in areas of policy complexity to improve functionality and decrease transaction costs. In recent years policy making has become more technically complex and requires interaction between different policy areas. ${ }^{21}$ Political actors may not have the resources or the incentive to develop such expertise for themselves and may require the support of policy experts. ${ }^{22}$ Furthermore, since independent institutions are closer to the regulated sector than ordinary bureaucracy, they may be able to adjust regulations to changing conditions and enhance efficiency in rule making. ${ }^{23}$ Second, a government may delegate authority to independent bodies to partially shift the blame for unpopular policies or regulatory failure. In particular, Fiorina argues that with delegation "legislators not only avoid the time and trouble of making specific decisions, they avoid or at best disguise their responsibility for the consequences of the decisions ultimately made."24 Third, political uncertainty, short-term goals, and poor credibility are intrinsic problems of democratic governance. Therefore, a further reason to delegate authority is to enhance political stability and increase the credibility of political commitments. ${ }^{25}$ Since independent bodies are isolated from daily political influence or electoral constraints and have a longer time-horizon than politicians, they have the potential to increase the credibility of governments' commitments and help pursue policy objectives more efficiently. ${ }^{26}$ As a result, a government may delegate power on the assumption that independent experts will be able to balance conflicting interests and thus make better decisions in the public interest. ${ }^{27}$ In addition, delegation may ensure that a government's policies last beyond its term of office or will not be easily changed in the future by political opponents. ${ }^{28}$ Finally, administrative bodies may offer the advantage of low-cost expert tribunals because, due to their structure,

Robert Elgie \& Iain McMenamin, “Credible Commitment, Political Uncertainty or Policy Complexity? Explaining Variations in the Independence of Non-Majoritarian Institutions in France” (2005) 35:3 British J Political Science 531 at 534.

22 Ibid.

23 Mark Thatcher \& Alec Stone Sweet, "Theory and Practice of Delegation to Non-Majoritarian Institutions" (2002) 25:1 West European Politics 1 at 4.

24 Morris P Fiorina, “Legislative Choice of Regulatory Forms: Legal Process or Administrative Process?” (1982) 39 Public Choice 33 at 47. See also Murray Rankin, "The Cabinet and the Agencies: Toward Accountability in British Columbia" (1985) 19:1 UBC L Rev 25 at 34 (discussing a system of "selective accountability").

$25 \quad$ See Giandomenico Majone, "Strategy and Structure the Political Economy of Agency Independence and Accountability" in OECD, Working Party on Regulatory Management and Reform, Designing Independent and Accountable Regulatory Authorities for High Quality Regulation (London: OECD, 2005) 126 at 130, online: <www.oecd.org/site/govgfg/39609070.pdf> [Majone, "OECD Report"] (arguing that the need to achieve stability and credible long-term commitments is the main rationale today for delegating authority to independent institutions).

26 Murray J Horn, The Political Economy of Public Administration (Cambridge: Cambridge University Press, 1995) at 17, citing Terry M Moe, "Political Institutions: The Neglected Side of the Story" (1990) 6:3 JL Econ \& Org 213 at 227 (arguing that political actors know that whatever policies and structures they put in place today may be subject to the authoritative direction of other actors tomorrow, actors with different interests who could undermine or destroy their hard-won achievements). See also Terry M Moe, "The Politics of Structural Choice: Toward a Theory of Public Bureaucracy" in Oliver E Williamson, Organization Theory: From Chester Barnard to the Present and Beyond (New York: Oxford University Press, 1995) 116 at 124, 136 (stating that "[t]he group's task in the current period ... is to build agencies that are difficult for its opponents to gain control over later ... this often means building agencies that are insulated from public authority in general-and thus from formal control by the group itself”); Majone, “OECD Report," ibid at 102; Elgie \& McMenamin, supra note 21 at 533.

27 Clare Hall, Colin Scott \& Christopher Hood, Telecommunications Regulation: Culture, Chaos and Interdependence Inside the Regulatory Process (London: Routledge, 2000); see also Larsen et al, supra note 20 at 2859-60; Philip Bryden, "How to Achieve Tribunal Independence: A Canadian Perspective" in Robin Creyke, ed, Tribunals in the Common Law World (Sydney: Federation Press, 2008) 62 at 6465.

Ibid. 
they may be able to gather relevant information and carry out adjudicative functions with more efficiency than courts. ${ }^{29}$

While a government may establish an agency as independent or arm's length, in practice no institution is completely autonomous. ${ }^{30}$ All administrative bodies are expected to exercise their functions within the government policy framework, and to implement those polices in an independent, professional, and transparent manner. ${ }^{31}$ Furthermore, they must do so in accordance with the rule of law. ${ }^{32}$ Since they are not elected bodies, there has been much discussion concerning their accountability and the legitimacy of their decisions, especially decisions that may have far-reaching policy implications. ${ }^{33}$ Certainly, some administrative agencies have large statutory mandates that are open to a broad suite of different interpretations and considerable discretion. ${ }^{34}$ Some may operate in fields that are also occupied by departments of a government, which may enhance the desire of a government to have more control over policy development within the agencies. ${ }^{35}$

In this context, ministerial directions are generally proposed as an instrument to provide guidance, ensure accountability, and ensure consistent application of policies between the executive, or a department of the executive, and the agency. ${ }^{36}$ However, ministerial directions are very controversial and the interference of the executive branch is often seen as an unjustifiable threat. ${ }^{37}$ Some argue that the executive branch should refer any specific concerns and policy changes to the legislature to avoid undermining the integrity of the decision-making process and raising questions about who is really in charge. ${ }^{38}$ Accountability for decision-making is owed to the legislature, not cabinet, and if the legislature wishes to maintain the integrity of the process it should be careful about delegating supervisory responsibility to the executive. ${ }^{39}$

Majone, “OECD Report,” supra note 25 at 102 (the author also states that independent agencies may constitute a more attractive environment for neutral experts). See McKenzie v Minister of Public Safety and Solicitor General, 2006 BCSC 1372, 61 BCLR (4th) 57 at para 66 [McKenzie].

$30 \quad$ See HN Janisch, "Independence of Administrative Tribunals in Canada: In Praise of 'Structural Heretics'” (1988) 8:2 J National Assoc Admin L Judges 75 at 79, online: < digitalcommons.pepperdine. edu/naalj/vol8/iss2/1> (stating that 'independence' can in no sense be absolute). Larsen et al, supra note 20 at 2859-60; Sossin, supra note 20 at 2, 9; Canada, Telecommunications Policy Review Panel: Final Report (Ottawa: Public Works and Government Services Canada, 2006) at 9-15, online: <www.ic.gc.ca/eic/site/smt-gst.nsf/vwapj/tprp-final-report-2006.pdf/ \$FILE/tprp-finalreport-2006.pdf> [Telecommunications Policy Review Panel].

32 Dunsmuir v New Brunswick, 2008 SCC 9, [2008] 1 SCR 190 at para 125.

33 Larsen et al, supra note 20 at 2859-60; Sossin, supra note 20 at 9; Majone, “OECD Report," supra note 25 at 128; Public Agencies Governance Framework, supra note 19 at 6; McCrank, Hohol \& Tupper, supra note 19 at 21; Rankin, supra note 24 at 34.

34 Law Reform Commission of Canada, Independent Administrative Agencies (Ottawa: Law Reform Commission of Canada, 1985) at 25, online: <www.lareau-legal.ca/LRCReport26.pdf> [Independent Administrative Agencies].

35 Ibid. For example, in Alberta, this tension was evident in the package of amendments to various provincial statutes that was adopted in 2010 with Bill 24, Carbon Capture and Storage Statutes Amendment Act, 2010, 3rd Sess, 27th Leg, Alberta, 2010, to provide for the regulation of carbon capture and storage projects in the province. Under this scheme, the Department of Energy has assumed a number of technical responsibilities that one might have expected to be assigned to the ERCB, including issuing the closure certificate for a CCS project. For further details on this discussion, see Nigel Bankes "Alberta makes significant progress in establishing a legal and regulatory regime to accommodate carbon capture and storage (CCS) projects” (3 November 2010), ABlawg (blog), online: <ablawg.ca/wpcontent/uploads/2010/11/blog_nb_ccsNov2010.pdf>.

Independent Administrative Agencies, supra note 34 at 25.

Ibid.

Ibid.

Ibid at 44. 
When important changes to the overall objectives of the agency are involved, it may be easy to agree that the legislature should be in charge of legitimizing those changes. However, policy is by nature dynamic and governments have an ongoing role in refining existing policies and developing new policies to anticipate or respond to changing conditions. ${ }^{40}$ Not all policy can be rooted in legislation because sometimes the parliamentary process is too slow or of peripheral interest to the government such that addressing it through legislation may be inefficient. ${ }^{41}$ As a result, ministerial directions are appealing when timely guidance from the government is needed to ensure that regulatory boards do not compromise larger policy goals. ${ }^{42}$

Despite these advantages, there seems to be broad consensus that routine involvement by the executive may undermine the very reasons that prompted governments to create independent agencies. The greatest danger with ministerial directions arises if a government issues a direction with the intent of influencing a policy question that has arisen in the context of an existing application before the agency. ${ }^{43}$ The tension that generally arises is that a public agency or officer may have a duty to comply with the direction but must also make a decision fairly. ${ }^{44}$ Even though it may seem a practical approach for the government to attempt to provide guidance to the administrative agency, some may question whether the direction entailed policy-making or was an illegitimate attempt to interfere with the procedure of the specific case. ${ }^{45}$

Ministerial directions may also give rise to lobbying battles to overturn decisions reached in a more transparent regulatory process. ${ }^{46}$ As a result, while applicants may still formally proceed before the regulatory agency, their real efforts may move to influence the minister who might in turn affect the content of the direction. ${ }^{47}$ It is not only the government that may abuse directions and raise doubts about the integrity of the whole process, but also the regulatory agencies themselves. ${ }^{48}$ For instance, in some tough cases, an agency may be

Telecommunications Policy Review Panel, supra note 31 at 9-15.

Andrew J Roman, "Governmental Control of Tribunals: Appeals, Directives, and Non-Statutory Mechanisms” (1985) 10:2 Queen’s LJ 476 at 486, 492.

Independent Administrative Agencies, supra note 34 at 26.

Ibid at 25.

See e.g. Baker v Canada (Minister of Citizenship and Immigration), [1999] 2 SCR 817 at paras 18-26 (concerning procedural fairness and bias of public officials) and the opinion of Justice Rand in Roncarelli $v$ Duplessis, [1959] SCR 121 (concerning the improper exercise of discretionary power by government officials).

See e.g. Shaw v Alberta (Utilities Commission), 2012 ABCA 100, 72 Alta LR (5th) 23 [Shaw] (The Alberta Utilities Commission approved the construction and operation of a proposed major electrical transmission line and substation known as the Heartland Transmission Project. This project was the first one considered under Bill 50. Those opposed to the project brought an application for leave to appeal Commission's decision. The test for leave to appeal was satisfied on certain grounds of appeal. In particular, the second ground of appeal was based upon the intervention of the Minister of Energy, who wrote two letters to the Chairman of the Commission requesting that the Commission adjourn or suspend its consideration of the Heartland Transmission Project. The Court found that it was arguable that the alleged interference of the Minister would cause a reasonable person to apprehend bias). See also Fluker, supra note 16 at 3 (questioning the independence of the Alberta Energy Regulator); Independent Administrative Agencies, supra note 34 at 25; Majone, “OECD Report,” supra note 25 at 129.

Telecommunications Policy Review Panel, supra note 31 at 9-16 (arguing that "[s]ince regulatory battles are primarily waged between private sector competitors, any Cabinet review can be viewed as a choice between competing commercial interests, rather than between competing policy alternatives”); Roman, supra note 41 at 492.

Roman, ibid (arguing that lobbying efforts may raise concerns about equity and democracy, and those with narrow short-term commercial interests at stake may likely prevail over those groups with broader public or private interests). Ibid at 491. 
tempted to seek clarification from the minister to reduce the risk of appeals or to find relief from the criticisms of an unpopular decision. ${ }^{49}$

The extent to which the legislature should allocate responsibility to the executive or to an "independent" agency is a question of political judgment and raises larger issues. ${ }^{50}$ However, while accountability might be achieved by placing responsibility for decision-making in the hands of a political body such as cabinet, "[p]olitical decision-making is not an end in itself, but a means to an end - and that is accountability to the public for achievement of public goals." 51 To maintain its integrity and make better decisions in the public interest an independent agency is expected to bring some autonomy of thought to the decision even though this may entail leaving it some room to make policy determinations. ${ }^{52}$ In any case, as Murray Rankin, Member of Parliament, notes, many of the technical or narrow issues decided by regulatory agencies are generally not the ones upon which governments are elected or defeated. ${ }^{53}$

\section{ANALYSIS OF SECTION 67 OF REDA}

This part analyzes the power of the Minister under section 67 of REDA and attempts to determine its scope and implications.

\section{A. TeXt OF SEction 67}

Section 67 reads as follows:

(1) When the Minister considers it to be appropriate to do so, the Minister may by order give directions to the Regulator for the purposes of

(a) providing priorities and guidelines for the Regulator to follow in the carrying out of its powers, duties and functions, and

Ibid.

See e.g. Ocean Port Hotel Ltd v British Columbia (General Manager, Liquor Control and Licensing Branch), 2001 SCC 52, [2001] 2 SCR 781 at para 24 [Ocean Port] (Chief Justice McLachlin, for the majority of the Supreme Court, stated that "given their primary policy-making function, it is properly the role and responsibility of Parliament and the legislatures to determine the composition and structure required by a tribunal to discharge the responsibilities bestowed upon it").

Richard Schultz, Frank Swedlove \& Katherine Swinton, "The Cabinet as a Regulatory Body: The Case of the Foreign Investment Review Act” (1980) Economic Council of Canada Working Paper No 6 at 88. Independent Administrative Agencies, supra note 34 at 22; Bryden, supra note 27 at 72-74; HN Janisch, "Policy Making in Regulation: Towards a New Definition of the Status of Independent Regulatory Agencies in Canada” (1979) 17:1 Osgoode Hall LJ 46 at 47 (quoting Guy Roberge, Vice Chairman of the Canadian Transport Commission, who stated "a regulatory body cannot be half-slave and half-free"). Rankin, supra note 24 at 53. 
(b) ensuring the work of the Regulator is consistent with the programs, policies and work of the Government in respect of energy resource development, public land management, environmental management and water management.

(2) The Regulator shall, within the time period set out in the order, comply with directions given under this section. ${ }^{54}$

\section{B. Who MAY ISSUE DiRECTIONS UNDER SECTION 67 OF REDA?}

The responsibility for section 67 of $R E D A$ “is transferred to the common responsibility of the Minister of Energy and the Minister of Environment and Sustainable Resource Development.” 55 The Government Organization Act provides that, when two or more ministers are given common responsibility for the exercise of the same provision, any reference in the provision to a minister is to be read as a reference to any of those ministers. ${ }^{56}$ Thus, it may be inferred that the power to issue directions under section 67 of REDA is assigned disjunctively to the Minister of Energy and Minister of Environment and Sustainable Resource Development.

Generally, the statutory power to give directions to energy regulatory boards is assigned to the Lieutenant Governor in Council. ${ }^{57}$ This approach also seems to be common outside the oil and gas sectors. ${ }^{58}$ The difficulty with the approach adopted under section 67 of REDA is that a single minister may not have the required skills or tools to address broader governmental policies, or it may be difficult for them to coordinate their work. ${ }^{59}$ In addition, a single minister may be individually exposed to conflicts with stakeholders and the general public. ${ }^{60}$ Even though the Policy Management Office may address some of the above issues, there is currently not enough information to determine how this office will exactly operate and coordinate with the Ministers. ${ }^{61}$

\section{Purposes Under Section 67 OF REDA}

Directions may be issued to the Regulator for two purposes. First, directions may be issued to provide priorities or guidelines that the Regulator must use in carrying out its "powers, duties and functions" (subsection (a)). ${ }^{62}$ Second, directions may be issued to ensure that "the work of the Regulator is consistent with the programs, policies and work of the Government” (subsection (b)). ${ }^{63}$

It is not entirely clear how these two subsections of section 67(1) REDA should be read, and what legal effects the conjunction and at the end of subsection (a) produces. In other

REDA, supra note 8, s 67.

Designation and Transfer of Responsibility Regulation, Alta Reg 80/2012, s 6(1.1).

Government Organization Act, RSA 2000, c G-10, s 16(4).

See discussion in Part IV, below.

See e.g. Nuclear Safety and Control Act, SC 1997, c 9, s 19; Telecommunications Act, SC 1993, с 38, s 8; Broadcasting Act, SC 1991, c 11, s 7.

For a general discussion on this point, see Independent Administrative Agencies, supra note 34 at 28. Ibid.

The Policy Management Office is discussed in Part III.G, below.

REDA, supra note 8, s 67(1)(a).

Ibid, s 67(1)(b). 
words, could the Minister give directions to the Regulator for the sole purpose of providing priorities on the powers, duties, and functions of the Regulator? Alternatively, could the Minister give directions to the Regulator for the sole purpose of ensuring that the work of the Regulator is consistent with the programs, policies, and work of the Government? Or is the Minister only allowed to issue directions that have both purposes concurrently?

As pointed out by Professor Dickerson, the conjunction and is semantically ambiguous as "it is not always clear whether the writer intends the several "and" (A and B, jointly or severally) or the joint "and" (A and B, jointly but not severally)." ${ }^{\text {" }}$ Both uses are grammatically correct and common in both popular and legal language. ${ }^{65}$ Determining which meaning is appropriate depends on the context. ${ }^{66}$ Professors Dickerson and Driedger indicate that, in an enumeration of powers in the legislation, the conjunction and tends to be used with the several meaning. ${ }^{67}$ In particular, "if the separate items are joined by and, the powers are normally regarded as joint and several, and the authority may exercise all or any of them."68 However, Professor Sullivan indicates that this presumption may be rebutted by linguistic considerations or by knowledge of the world. ${ }^{69}$

Based on this analysis, the conjunction and at the end of subsection (a) arguably creates the presumption that the Minister may issue directions for all the purposes indicated in section 67(1) or any of those purposes individually. However, the debate in the Legislature on section 67 of REDA may help to rebut this presumption. ${ }^{70}$ When Bill 2 (REDA) was under

Reed Dickerson, The Fundamentals of Legal Drafting, 2nd ed (Boston: Little, Brown \& Company, 1986) at 105. See also EA Driedger, Construction of Statutes, 2nd ed (Toronto: Butterworths, 1983) at 15. However, Professor Dickerson notes that even though and sometimes can produce a similar result to or, saying that and may mean or is inaccurate.

65 Driedger, ibid at 16.

$66 \quad$ Ibid at 18

Ibid at 16; Reed Dickerson, Materials on Legal Drafting (St Paul, Minnesota: West Publishing, 1981) at 250-51; Ruth Sullivan, Sullivan on the Construction of Statutes, 5th ed (Markham: LexisNexis Canada, 2008) at 82-83.

Driedger, supra note 64. A number of courts have adopted a similar analysis. See e.g. $R v$ Welsh (No 6) (1977), 15 OR (2d) 1 (CA).

$69 \quad$ Sullivan, supra note 67 at 83.

70 See e.g. Ruth Sullivan, Statutory Interpretation (Concord: Irwin Law, 1997) at 199. In Rv Morgentaler, [1993] 3 SCR 463 at para 31, the Supreme Court of Canada held that Hansard and government publications are admissible evidence of legislative intent in constitutional cases. The Court stated that "[p]rovided that the court remains mindful of the limited reliability and weight of Hansard evidence, it should be admitted as relevant to both the background and the purpose of legislation. Indeed, its admissibility in constitutional cases to aid in determining the background and purpose of legislation now appears well established.” See also Reference re Firearms Act (Canada), 2000 SCC 31, [2000] 1 SCR 783 at para 17 (stating that "[w]hile such extrinsic material was at one time inadmissible to facilitate the determination of Parliament's purpose, it is now well accepted that the legislative history, Parliamentary debates, and similar material may be quite properly considered as long as it is relevant and reliable and is not assigned undue weight”). The admissibility of Hansard for statutory interpretation in nonconstitutional cases remains uncertain but there is a trend towards allowing this type of evidence. See e.g. Shaw, supra note 45. In that case the Alberta Court of Appeal had to determine under Bill 50 whether and how the amendments to the Commission's governing statutes altered the scope of the public interest inquiry delegated to the Commission in assessing a project designated as critical transmission infrastructure. The Court at para 39 states that "Canadian courts have long recognized that legislative history can play a useful, if limited, role in the interpretation of legislation.... Although, in my view, it is not necessary to resort to the Hansard debates to discern the legislative intent in enacting Bill 50 (which is clear on the face of the legislation), a review of those debates bolsters the conclusion reached by the Commission.” Similarly, the Ontario Superior Court of Justice in Branch $v$ Ontario (Minister of Environment) (2009), 93 OR (3d) 665 (Sup Ct J) at para 20 held that "[l]egislative debates are admissible as evidence of the intent or purpose of the legislature in enacting the legislation, although a court must be mindful of the limited reliability and weight of Hansard evidence.” In that case the Ontario Superior Court of Justice relied on the legislative debate to interpret the Environmental Protection Act, RSO 1990, c E-19, s 163.1(2). 
consideration, the opposition Liberal Party made a motion to strike out subsection (b), describing it as “entirely redundant” or potentially misleading. The following excerpt of the Alberta Hansard provides the discussion on this motion.

Hon. member, you may speak to the amendment.

Dr. Swann: Thank you very much, Mr. Chair. Under part 4 Mr. Hehr moves that Bill 2, Responsible Energy Development Act, 2012, be amended in section 67(1) by striking out the word “and” at the end of clause (a) and striking out all of clause (b), which appears to be entirely redundant. (...)

We fail to see how that [subsection (b)] adds materially to the bill and may give a false impression to some ministers that they can carry out far more intervention than is appropriate. So we see nothing that isn't included under subsection (a) and would suggest that part (b) is either redundant or could be misused. Thank you, Mr. Chair.

The Chair: The hon. Government House leader.

Mr. Hancock: Thank you, Mr. Chair. I'd have to speak against this amendment. Clause (b) is clearly a very important part of the bill. What the report that was done as a backdrop to this bill very clearly set out is that in order for us to do appropriate sustainable development in this province, balancing the interests of industrial development and the environment, the interest of Albertans, there needs to be a policy process that's set by government through the Legislature on behalf of Albertans. The government sets the policy. The Legislature sets the legislation. Those are the structures that are put in place. The regulators don't make policy. They carry out policy in terms of implementation.

Section 67(1) very clearly says in (a) that the minister can give priorities and guidelines in terms of how they carry out their duty and in (b) ensures that the way they carry out their duty is done in compliance with the policies, rules, and processes set out by government. It sets out the very clear delineation of responsibility.

Policy is the role of government and the Legislature. Carrying out the policy with respect to this area is the role of the regulator. ${ }^{71}$

The Opposition did not succeed in its attempt to amend section 67 of REDA. As seen in the above discussion, in response to the motion to strike out subsection (b), the Government House Leader emphasized that the importance of subsection (b) is to establish a policy process that is set by the government and to set a clear delineation of responsibility between policy-making (assigned to the Government of Alberta) and policy implementation (assigned to the Regulator).

Based on the statements of the Government House Leader, the role of subsection (a) is unclear if the powers under subsection (a) and (b) are several. A main underlying purpose of executive directions is precisely to allow a government to provide policy guidance to regulators and coordinate their work within the broader framework, regardless of whether or not the provision expressly indicates this purpose. In this context, the criticism of the 
Opposition that subsection (b) is "redundant" seems understandable. Also, the effect of viewing the powers as several is that under subsection (b) the Ministers might claim to have a power that goes beyond setting priorities and guidelines such as the power to exercise political control over the adjudicative functions of the Regulator (although this interference would still be prohibited by the Alberta Public Agencies Governance Act). ${ }^{72}$ The whole discussion of the Government House Leader does not seem to support this interpretation; rather, it seems to suggest that the main concern of the Alberta Government was to ensure that section 67 of REDA would clearly allow it to set policy guidelines and legitimately require the Regulator to comply with them. That the Government wanted this purpose to be expressly stated in the legislation for sake of clarity does not seem to be an issue. However, the above discussion supports the argument that the powers under subsection (a) and (b) are joint and not several. This interpretation only allows the Minister to set priorities and guidelines for the Regulator to ensure that the work of the Regulator is in compliance with the policy framework set out by the Government.

\section{THE LEgAL STATUS OF A DiRECTION ISSUED UNDER SECTION 67 OF REDA}

Before analyzing the legal status of a ministerial direction issued under section 67 of $R E D A$, it is necessary to discuss the status of ministerial directions in general. This discussion is necessary because of the uncertainties and lack of clarity concerning ministerial directions, exacerbated by the fact that the term direction is often used interchangeably with other terms such as guidelines, directives, rules, ordinances, or circulars and that all of these terms are generally undefined in the applicable legislation.

The Supreme Court of Canada has indicated that when the term of the instrument is not defined in the statute, the term in itself is not indicative of its legal status or effects and it is necessary to look at its substance. ${ }^{73}$ It seems that three different types of guidance can be distinguished: informal policy statements, administrative policy directions, and policy directions having the nature of delegated legislation. ${ }^{74}(1)$ Informal policy statements are an

72 See discussion in Part III.E, below.

73 Friends of the Oldman River Society $v$ Canada (Minister of Transport), [1992] 1 SCR 3 at 34 [Friends of the Oldman River Society]. See also $R v$ Simmermon (1996), 37 Alta LR (3d) 298 (CA) for the proposition that, in the absence of some express statutory distinction based on nomenclature, the nature of a statutory instrument should be decided on its substance, not its form (at para 12): "If the substance and effect of the instrument is legislative, it will be treated as a regulation.” The Court's ruling on this point is based upon, and supported by, the decision in Canadian Pacific Ltd $v$ Canada (Canadian Transport Commission), [1985] 2 FCR 136 (CA).

74 There is also the type of policy statements issued by the agency itself that are in the nature of selfimposed limitations on discretion. See British Columbia Hydro and Power Authority v British Columbia (Utilities Commission) (1996), 20 BCLR (3d) 106 (CA). In that case, the Utilities Commission issued guidelines for the utility planning process. The guidelines stated that they did not mandate a specific outcome to the planning process or take away responsibility for making decisions from utility management, but rather that consistency with the guidelines would be an additional factor that the Commission would consider in judging the prudence of investments and rate applications. The Commission made an order against the applicant, a public utility company, outlining the Commission's finding that the applicant had not complied with the guidelines. The order required the applicant to comply with certain directions relating to the guidelines and threatened sanctions should the applicant fail to implement the directions. The applicant appealed from the order and applied for a declaration that the guidelines related to aspects of the order that were void on the ground that Commission had exceeded its jurisdiction in giving the guidelines the force of a Commission order. Held: The declaration was granted. The enforcement by order of the guidelines was an exercise of management of a public utility business beyond the scope of the powers granted to the Commission under the Act. Looking at the Act as a whole, it did not reflect any intention on the part of the legislature to confer upon the 
expression of purpose of a government. ${ }^{75}$ They may emerge in ministerial speeches or in announced government programs. ${ }^{76}$ These statements generally have no legally binding effects. $^{77}$ (2) A government may give administrative directions to dictate administrative policy within the ranks of government departments. They may be binding on those to whom the direction is addressed depending on whether they are drafted in indicative or imperative terms. ${ }^{78}$ Administrative directions do not need to be authorized by statute because "a minister has an implicit power to issue directives to implement the administration of a statute for which he is responsible."79 Sometimes they are authorized by statute, but nonetheless the case law seems to suggest that the infringement of administrative directions can only have administrative and non-judicial consequences. ${ }^{80}$ Administrative directions might create a legitimate expectation that the public officer or agency will follow a certain procedure depending on the content of the direction and whether it is drafted with mandatory language. ${ }^{81}$ Their infringement may be subject to judicial review, ${ }^{82}$ however, they generally do not create substantive rights regardless of whether third parties are adversely affected by non-compliance with the direction. ${ }^{83}$ (3) Finally, there are directions that are in the nature of delegated legislation or regulations. The power to issue this type of direction only exists if provided for by statute. ${ }^{84}$ These directions bind all those to whom the direction is addressed, create substantive rights on third parties, and are legally enforceable in court. ${ }^{85}$ It may not be

Commission a jurisdiction to determine, punishable on default by sanctions, the manner in which the directors of a public utility were to manage its affairs.

Independent Administrative Agencies, supra note 34 at 24, n 28.

Ibid.

Ibid, n 29 ("The Cabinet review/ appeal process can, in some cases, be used in such a way that it makes enforceable 'non-binding' statements of policy”).

78 For instance, in Maple Lodge Farms Ltd v Canada, [1982] 2 SCR 2 [Maple Lodge], the Supreme Court found that the public servants to whom the directives applied were free to decide whether or not to obey them since the directives were worded in an indicative manner. By contrast, the directives issued by the Commissioner of Penitentiaries in Martineau v Matsqui Institution Inmate Disciplinary Board, [1978] 1 SCR 118 [Martineau], were found to be mandatory on the public servants involved because they clearly indicated an intention to bind those to whom the directive was addressed.

$79 \quad$ Friends of the Oldman River Society, supra note 73 at 35 (stating that "[t]here is little doubt that ordinarily a Minister has an implicit power to issue directives to implement the administration of a statute for which he is responsible; ... It is also clear that a violation of such directives will only give rise to administrative rather than judicial sanction because they do not have the full force of law"). See also Martineau, ibid at 129 , stating that:

[i]t is significant that there is no provision for penalty and, while they are authorized by statute,

they are clearly of an administrative, not a legislative, nature. It is not in any legislative capacity

that the Commissioner is authorized to issue directives but in his administrative capacity. I have

no doubt that he would have the power of doing it by virtue of his authority without express

legislative enactment. It appears to me that s. 29(3) is to be considered in the same way as many

other provisions of an administrative nature dealing with departments of the administration which

merely spell out administrative authority that would exist even if not explicitly provided for by statute.

Friends of the Oldman River Society, ibid.

See e.g. Martineau, supra note 78.

Peet v Canada (Attorney General), [1994] 3 FCR 128 (TD) [Peet].

Ibid. In that case, the Court discussed decisions taken under directives that had been issued by the Commissioner of Penitentiaries. The Commissioner's authority to issue these directives derived from section 29(3) of the Penitentiary Act, RSC 1970, c P-6. The majority of the Court, at 129, held that a review of the decision in question was not within the jurisdiction of the Federal Court of Appeal because the directives were administrative and did not have the force of law. Friends of the Oldman River Society, supra note 73 at 35; Hassum v Contestoga College Institute of Technology and Advanced Learning, 2008 CanLII 12838 (Ont Sup Ct J) at paras 27, 77, online: <http://canlii.ca/t/1w8np> [Hassum]. 
easy to challenge them on the ground that they fettered the discretion of the decision-maker. ${ }^{86}$ Also, since they must be interpreted and applied as any other law, an interested party may have a direction enforced by way of prerogative relief, including mandamus or certiorari, if the public officer or agency does not comply with the direction. ${ }^{87}$ Similarly, a decision of the agency may be subject to judicial review to determine whether or not it complies with the direction or whether the agency committed an error in law in its dispositions. ${ }^{88}$

The test for whether policy directives, guidelines, circulars, directions or other instruments authorized under a statute have the force of law was set out in Friends of the Oldman River Society v. Canada (Minister of Transport). ${ }^{89}$ In that case, the court had to consider an application brought by a third party seeking an order for certiorari and mandamus to require the Minister of Transport and the Minister of Fisheries and Oceans to conduct an environmental assessment in compliance with the federal Environmental Assessment and Review Process Guidelines (Guidelines). The principal ground on which the Crown contended that the Guidelines were ultra vires is that, by using the term "guidelines," section 6 of the Department of the Environment Act ${ }^{90}$ could not empower the enactment of mandatory subordinate legislation, but only administrative directives not intended to be legally binding on those to whom they were addressed. ${ }^{91}$ In determining whether the Guidelines were subordinate legislation or administrative directions, the Supreme Court determined that the denomination of the instrument in itself is neutral, and formulated a twostep analysis. ${ }^{92}$ First, the enabling statute needs to be analyzed to determine whether it supports the power to create subordinate legislation of a mandatory nature. ${ }^{93}$ This is a question of legislative intent and the wording of the authorizing provision must be considered as a whole. ${ }^{94}$ Second, the specific direction, guideline, directive or other instrument needs to

See e.g. Bell Canada Inc v Canadian Telephone Employees Association, 2003 SCC 36, [2003] 1 SCR 884 at paras 35-38, 45 [Bell]. In that case, the independence and impartiality of the Canadian Human Rights Tribunal were challenged due to the power of the Canadian Human Rights Commission to issue binding guidelines to the Tribunal. When Bell started the lawsuit, the Commission had the broad power to make guidelines concerning the application of the Act in a particular case, but the legislation was subsequently amended to allow guidelines to be issued only in relation to a "class of cases.” The Court ruled that general guidelines having the form of delegated legislation and falling within the scope of statutory authority are similar to regulations, and may be a way for Parliament to ensure that the Act will be interpreted in a manner that furthers the ultimate purpose of the Act as a whole. However, sufficient evidence that, in practice, the guidance has unduly influenced the impartiality of the tribunal in a specific case may produce a different result.

$87 \quad$ See e.g. Friends of the Oldman River Society, supra note 73.

$88 \quad$ See e.g. BC Hydro and Power Authority v Terasen Gas (Vancouver Island) Inc, 2004 BCCA 346,30 BCLR (4th) 305; BC Hydro and Power Authority $v$ Terasen Gas (Vancouver Island) Inc, 2003 BCCA 594, [2003] BCJ No 2531 (QL) (the issue arose from an order of the British Columbia Utilities Commission setting rates for the transmission and distribution of natural gas on Vancouver Island. The British Columbia Hydro and Power Authority contended that the order was unlawful essentially because it conflicted with a Special Direction issued by the Lieutenant Governor-in-Council determining on rates); see also Yukon Energy Corp v Yukon Utilities Board (1996), 74 BCAC 58 (CA) (in that case, the Utility board made certain orders in a decision on an application by utility companies for approval of changes in rates charged for electricity. The utility companies appealed orders alleging jurisdictional error and errors of law by the board).

$89 \quad$ Friends of the Oldman River Society, supra note 73 at paras 35-36.

90 RSC 1985, c E-10. Section 6 reads as follows:

For the purposes of carrying out his duties and functions related to environmental quality, the

Minister may, by order, with the approval of the Governor in Council, establish guidelines for use

by departments, boards and agencies of the Government of Canada and, where appropriate, by corporations named in Schedule III to the Financial Administration Act and regulatory bodies in the exercise of their powers and the carrying out of their duties and functions. Friends of the Oldman River Society, supra note 73 at 33.

Ibid at 34-35.

Ibid at 33.

Ibid at 34-35. 
be analyzed to determine if it is framed as mandatory. ${ }^{95}$ This is a question of fact and the answer depends on the wording of the direction and, for example, whether it uses terms such as "shall" or "must." 96 The Court also quoted the following passage of Dussault and Borgeat to emphasize the "vital distinction" between administrative instruments (intended for the control of public servants under a minister's authority), and instruments having the nature of subordinate legislation or regulation:

When a government considers it necessary to regulate a situation through norms of behaviour, it may have a law passed or make a regulation itself, or act administratively by means of directives. In the first case, it is bound by the formalities surrounding the legislative or regulatory process; conversely, it knows that once these formalities have been observed, the new norms will come within a framework of "law" and that by virtue of the Rule of Law they will be applied by the courts. In the second case, that is, when it chooses to proceed by way of directives, whether or not they are authorized by legislation, it opts instead for a less formalized means based upon hierarchical authority, to which the courts do not have to ensure obedience. To confer upon a directive the force of a regulation is to exceed legislative intent. It is said that the Legislature does not speak without a purpose; its implicit wish to leave a situation outside the strict framework of "law" must be respected. ${ }^{97}$

In this case, the Court concluded that the E.A.R.P. Guidelines were subordinate legislation and could be enforceable through prerogative relief despite being called “guidelines” because they were authorized by statute, were specifically framed in mandatory language, and had been promulgated by order-in-council. ${ }^{98}$

Turning the analysis back to section 67 of REDA, it does not seem possible to give a definite answer on whether a direction issued under this provision would have the nature of an internal administrative direction or the force of law. The characterization of a direction turns in part on the language of section 67 of REDA but also in part on the language of the direction itself (i.e. a conclusion about the characterization of one direction under this section may not be conclusive with respect to other directions). Despite the reference to "guidelines," section 67 of REDA unequivocally allows the Ministers to give mandatory directions to the Regulator because subsection (2) states that "[t]he Regulator shall, within the time period set out in the order, comply with directions given under this section." ${ }^{\text {"99 }}$ Determining whether or not section 67 of REDA allows the creation of delegated legislation is less straightforward. This issue arises because, as previously discussed, this power exists only if statutorily provided. ${ }^{100}$ However, the mere existence of a statutory power to issue directions is not in itself indicative. ${ }^{101}$ In Friends of the Oldman River Society the Court emphasized that if issuance of the instrument is subject to formal requirements, such as formal enactment by

$95 \quad$ Ibid.

97 René Dussault \& Louis Borgeat, Administrative Law: A Treatise, 2nd ed, translated by Murray Rankin (Toronto: Carswell, 1985) 338-39, cited in ibid at 36 [emphasis added].

98 Friends of the Oldman River Society, ibid. The Court, at 36 stated the following:

Here though we are dealing with a directive that is not merely authorized by statute, but one that is required to be formally enacted by "order", and promulgated under s 6 of the Department of the Environment Act, with the approval of the Governor in Council. That is in striking contrast with the usual internal ministerial policy guidelines intended for the control of public servants under the minister's authority. To my mind this is a vital distinction.

99 REDA, supra note 8, s 67(2).

$100 \quad$ Hassum, supra note 83 at para 26.

$101 \quad$ Maple Lodge, supra note 78. 
order in council and approval of the Lieutenant Governor-in-Council, then this may generally indicate that the legislature intended to allow the creation of delegated legislation. ${ }^{102}$ Subsequent cases have followed Friends of the Oldman River Society and distinguished administrative directions from directions that have the force of law primarily by analyzing whether the provision authorizing the creation of policy directions requires a procedure similar to the creation of legislative acts and regulations. ${ }^{103}$ Based on the case law, it may be argued that section 67 of REDA does not allow the Minister to create delegated legislation because there is nothing in section 67 of $R E D A$ indicating that the Legislature intended to confer on the Minister anything more than an administrative function. For instance, section 67 of $R E D A$ does not specifically require a formal procedure similar to the enactment of regulations, such as the approval of the Lieutenant Governor-in-Council or publication of directions in the Alberta Gazette. ${ }^{104}$ In addition, the general power to create regulations under REDA is assigned to the Lieutenant Governor-in-Council in Part 6 of the Act. ${ }^{105}$ This may indicate that the legislature did not intend to assign a similar function to an individual Minister under section 67 of REDA. By contrast, it may be argued that section 67 of REDA allows the Minister to create delegated legislation because section 67 of $R E D A$ requires directions to be issued by way of "order" and does not exclude that a direction under section 67 of REDA may have the status of regulation. In addition, the Interpretation Act defines a "regulation" as "a regulation, order, rule, form, tariff of costs or fees, proclamation, bylaw or resolution enacted (i) in the execution of a power conferred by or under the authority of an Act, or (ii) by or under the authority of the Lieutenant Governor-in-Council." ${ }^{106}$ However, the case law seems to focus on whether the provision authorizing the direction requires a procedure similar to the creation of legislative acts and regulations. Consequently, it may be difficult to conclude that section 67 of REDA allows delegated legislation given the absence of explicit procedural requirements under this provision.

Friends of the Oldman River Society, supra note 73 at 36. The conclusion of the Court strongly relied on the Department of Environment Act, supra note 90, s 6, which requires the approval of the Governorin-Council for Ministerial Orders issued under this provision.

Hassum, supra note 83 at para 23; Bell, supra note 86 at para 36 (according to the Court, the guidelines issued by the Commission under the Act are, like regulations, of general application since, under the amended section 27(2) of the Act, they must pertain to a class of cases. Furthermore, these guidelines are subject to the Statutory Instruments Act, RSC 1985, c S-22, and must be published in the Canada Gazette. Moreover, the process that is followed in formulating particular guidelines resembles the legislative process, involving formal consultations with interested parties and revision of the draft guidelines in light of these consultations.); See also Peet, supra note 82 at para 133; Hewko (Guardian ad litem of) v British Columbia (Attorney General), 2006 BCSC 1638, 2006 CarswellBC 2703 at paras 314, 318; Turner-Lienaux v Nova Scotia (Attorney General) (1993), 122 NSR (2d) 119 at paras 17-20; Thamotharem $v$ Canada (Minister of Citizenship and Immigration), 2007 FCA 198, [2008] 1 FCR 385 at para 68; Martineau, supra note 78 at 129, where the majority of the Court concluded that, as the directives in issue were not of a legislative nature, they were not subject to judicial review. In Friends of the Oldman River Society, supra note 73 at 34-35 the Court emphasized the importance of looking at the provision to determine whether is contains such requirements. For example, as discussed in Part IV below, directions to the BC Oil and Gas Commission, the BC Utilities Commission and $\mathrm{OEB}$ all require publication in the relevant Gazette. 


\section{E. Policy Directions in Relation to The AdJUdicATIVE FUnCTIONS OF THE REgUlatoR}

Like its predecessor ERCB, the Alberta Energy Regulator performs both regulatory and adjudicative functions. The new legislative scheme under REDA separates the corporate governance, operational responsibilities, and adjudicative functions of the Regulator. In particular, the chair and the board of directors are responsible for the general direction of the Regulator's business affairs and setting performance expectations for the Regulator and its chief executive officer. ${ }^{107}$ The chief executive officer reports directly to the chair and oversees day-to-day operations, including making decisions and delegating decision-making on applications, monitoring, remediation, and reclamation in relation to the closure of energy projects. ${ }^{108}$ Finally, hearing commissioners act as decision-makers on applications subject to hearings, regulatory appeals, and reconsiderations. ${ }^{109}$

Before REDA received Royal Assent, several critics, including Ecojustice and the Environmental Law Centre, publically recommended that section 67 be deleted from the Bill. ${ }^{110}$ Perhaps, the most significant concern is that the Minister will interfere with the adjudicative functions of the Regulator, thus undermining the independence of the Regulator and the integrity of the decision-making process. The general rules concerning the governance of public agencies address some of these concerns. In particular, they address the issue of whether the Minister may give directions concerning the adjudicative functions of the Regulator; the answer seems to be no. ${ }^{111}$ The Public Agencies Governance Framework, ${ }^{112}$ and the Alberta Public Agencies Governance Act, ${ }^{113}$ both attempt to balance ministerial accountability with the need for independence in some agencies’ decision-making. ${ }^{114}$ Section 10 APAGA reads as follows:

(1) Subject to subsection (2), a Minister who is responsible for a public agency may set policies that must be followed by the public agency in carrying out its powers, duties and functions.

REDA, supra note 8, ss 5-6.

Ibid, s 7.

Ibid, ss 11-13.

See "Legal Backgrounder, Bill 2: Responsible Energy Development Act” Ecojustice (May 2013), online: $<$ www.ecojustice.ca/wp-content/uploads/2015/03/REDA-backgrounder-May-2013.pdf>; Letter from Cindy Chiasson, Executive Director, Environmental Law Centre, to Ken Hughes, Minister of Energy (6 November 2012), online: <www.elc.ab.ca/Content_Files/Files/Bill_2_brief_Nov_2012.pdf>.

In 2007, the Alberta government launched an initiative to improve the transparency, accountability, and governance of the numerous public agencies existing in the province. The Task Force commissioned by the government identified approximately 250 agencies with different responsibilities, functions, and structures. See McCrank, Hohol \& Tupper, supra note 19 at 7, 12. To improve the transparency, accountability, and governance of public agencies, the Task Force recommended enhancing standardization and institutionalization, and passing a new piece of legislation. Furthermore, the Task Force (McCrank, Hohol \& Tupper, ibid at 17-18) recommended the following "functional classification" system based on the primary purpose of agencies: (i) Regulatory/adjudicative agencies; (ii) Public trusts; (iii) Corporate enterprises; (iv) Service delivery agencies; (v) Advisory agencies. Public Agencies Governance Framework, supra note 19.

Alberta Public Agencies Governance Act, SA 2009, c A-31.5 [APAGA]. Section 80(a) was proclaimed in force 8 July 2009. Sections 1-36, 38-44, 46-52, 54-63, 65-72, 74-79, 80(b)-(e) were proclaimed in force 12 June 2013.

See Public Agencies Governance Framework, supra note 19 (discussing accountability at 3, 5-6 but stating at 7 that "this Framework should not be construed so as to interfere with the principles of judicial independence and administrative law that are essential to the functioning of quasi-judicial agencies”); see also McCrank, Hohol \& Tupper, supra note 19 at 15 (stating that an agency "[i]s accountable to government through a defined reporting relationship, recognizing the need for quasi-judicial independence in some agencies' decision making). 
(2) A policy must not be set under this section

(a) in respect of a public agency’s adjudicative functions, or

(b) if an Act, the regulations under this Act or any other regulation made by the Lieutenant Governor in Council prohibits the making of policies of that type.

This provision allows a minister responsible for a public agency to set policies that must be followed by the agency in carrying out its powers, duties, and functions. ${ }^{115}$ However, this provision also prohibits a minister from setting policy on the public agency's adjudicative functions. ${ }^{116}$ The APAGA provides the following definition of "adjudicative function":

(i) a function assigned or authorized to be performed by the public agency under an enactment, the performance of which includes

(A) the making of binding decisions in respect of applications, if the enactment authorizes the public agency to hold hearings respecting the applications,

(B) the making of binding decisions in respect of disputes, other than disputes respecting applications, or

(C) the hearing of reviews or appeals and the making of binding decisions in respect of those reviews or appeals,

(ii) any alternative dispute resolution process that is ancillary to a function described in subclause (i), and

(iii) a function specified in the regulations. ${ }^{117}$

Section 2(1) of the APAGA makes the APAGA paramount over REDA. ${ }^{118}$ Thus, by reference to section 10(2)(a) APAGA, it seems that neither the Minister of Energy nor the Minister of Environment and Sustainable Resource Development are allowed to set mandatory polices on the adjudicative functions of the Regulator. Applying the definition of ‘adjudicative functions' provided under section 1(1)(a) APAGA, section 67 of REDA does not permit at least four types of direction. First, policy directions are not allowed with respect to binding decisions on applications, if the Regulator is authorized to hold hearings on those applications. ${ }^{119}$ Second, policy directions are not allowed with respect to the Regulator's

APAGA, supra note 113, s 10. For the general powers and responsibilities of ministers, see also ss 6-12. Ibid, s 10(2)(a). For a major restriction on the powers of the minister see also section 9(1)(a) (prohibiting the disclosure of information if it may "reasonably be expected to affect the independence of the public agency respecting that matter”).

Ibid, s 1(1)(a).

Ibid, s 2(1), "Except where this Act or the regulations provide otherwise, the provisions of this Act and the regulations under this Act prevail to the extent of any inconsistency or conflict with one or more provisions of any other enactment except the Freedom of Information and Protection of Privacy Act and the Health Information Act." No regulations have yet been issued under APAGA. REDA, supra note 8, s 34(2); APAGA, supra note 113, s 1(1)(a)(i)(b). 
making of binding decisions on disputes other than disputes on applications. ${ }^{120}$ Third, policy directions are not allowed on the hearing of reviews or appeals and the Regulator's making of binding decisions with respect to those reviews. ${ }^{121}$ Lastly, policy directions are not allowed on any alternative dispute resolution process that is ancillary to a function identified in (1), (2) or (3).

\section{F. Procedural ReQuirements}

Directions under section 67 of REDA must be issued by way of “order" and the Regulator must comply with these directions within a prescribed time period. ${ }^{122}$ Section 67 of REDA does not clarify if the Minister must follow a formal procedure to give orders, including their publication in the Alberta Gazette, or if an order might be issued by way of an informal communication between the Minister and the Regulator.

Given the reference to "order" in section 67(1) of REDA, it is arguable that a ministerial direction of a legislative nature issued under this provision must be filed with the Registrar and published in the Alberta Gazette. ${ }^{123}$ However, as previously discussed, it is not clear whether section 67 of REDA assigns to the Minister a legislative function or whether the function of the Minister under this provision is only administrative. ${ }^{124}$ If we assume (contra the tentative conclusion of Part III.D), that the Minister is allowed to issue an order of a legislative nature under section 67 of $R E D A$, the Minister has to comply with the procedure prescribed under section 3 of the Regulations Act. ${ }^{125}$ An order of a legislative nature that is not filed has no effect, and an unpublished order is not effective against a person unless that person has had actual notice of the order. ${ }^{126}$ By contrast, a ministerial order of an administrative nature presumably does not need to be filed or published in the Alberta Gazette.

The Ontario Court of Appeal in Rose v. The Queen. ${ }^{127}$ addressed the issue of whether an order in council was of a legislative nature and thus subject to the Ontario Regulations Act. ${ }^{128}$ In this case, the plaintiff was seeking a judgment for damages due to lack of maintenance of repair of a highway. ${ }^{129}$ By order in council, the Crown had transferred to the municipality

This would, for example, include a decision on a dispute concerning private surface agreements. See $R E D A$, ibid, ss 62-66 and the regulations enacted under it. For a discussion on the enforcement of private surface agreements see Giorilyn Bruno "Phase 2 of the Implementation of the Alberta Energy Regulator: The Private Surface Agreement Registry” (20 January 2014) ABlawg (blog), online: <ablawg.ca/2014/ 01/20/phase-2-of-the-implementation-of-the-alberta-energy-regulator-the-private-surface-agreementregistry>.

APAGA, supra note 113, s 1(1)(a)(i)(a).

REDA, supra note 8, ss 67(1)-(2).

Regulations Act, RSA 2000, c R-14, ss 2(1), 2(3), 3(1), 3(5).

See discussion in Part III.D, above.

See the combined effect of the Regulations Act, supra note 123, s 1(1)(f) and the Interpretation Act, supra note 106, s 1(1)(c).

Regulations Act, ibid, s 3(5).

Rose $v$ The Queen, [1960] OR 147 (CA) [Rose].

Regulations Act, RSO 1950, c 337. Section 3 of the Act provides the following: "[e]very regulation shall, within one month of the filing thereof, be published in The Ontario Gazette.” Section1(e) defines regulation as follows: “'[r]egulation’ means any regulation, rule, order or by-law of a legislative nature made or approved under any Act of the Legislature by the Lieutenant-Governor in Council, a minister of the Crown, a department of the public service, an official of the government or a board or commission all the members of which are appointed by the Lieutenant-Governor in Council." 
certain sections of a highway under section 71(2) of the Highway Improvement Act. ${ }^{130}$ However, the Crown did not file the order in council with the registrar and the municipality had no notice of it. ${ }^{131}$ Therefore, the municipality contended that the order had no effect and that, since the highway was still vested in the Department of Highways, the Crown was liable under section 87 of the Highway Improvement Act for the condition of non-repair. ${ }^{132}$ The Ontario Court of Appeal emphasized the following criteria in determining whether an order is of a legislative or administrative nature:

In coming to a conclusion as to the nature of the act performed, not only must one look at the substance rather than the form but indeed in the inquiry upon which one must embark, all the surrounding circumstances must be looked at and by that I include the nature of the body enacting the order in question, the subject matter of the order, the rights and responsibilities, if any, altered or changed by that order. ${ }^{133}$

The Ontario Court of Appeal concluded that the order was of a legislative nature. In doing so, the Court relied on the fact that the order altered the rights and responsibilities of the general public as well as the nature and extent of those responsibilities. ${ }^{134}$ Since the order had not been filed under the Regulations Act and the municipality had no actual notice of it, the Court concluded that the order had no effect and was not valid against the municipality. ${ }^{135}$ Thus, the Crown was liable to the plaintiff. In Reference re Manitoba Language Rights (No. $2)^{136}$ the Supreme Court of Canada addressed in a very different context the issue of whether an instrument is of a legislative nature. In that case, the issue was relevant to determine whether certain documents produced by the Government of Manitoba were required to be published in both English and French under section 23 of the Manitoba Act. ${ }^{137}$ The Supreme Court of Canada identified some criteria indicative of a legislative nature. These criteria can approximately be divided into the headings of form, content, and effect. ${ }^{138}$ These criteria do not operate cumulatively, and an instrument may be determined to be legislative in form, though not in content, but would nonetheless be determined to be of a legislative nature. ${ }^{139}$

Ibid at paras 7-8; Highway Improvement Act, RSO 1950, c 166, ss 71(2), 87.

Rose, ibid at paras 21-23.

Ibid at paras 14-17.

Ibid at para 31.

Ibid. The Ontario Court of Appeal also states that

[w]e think that to an extent generally applicable to the public or large segments thereof it alters rights and responsibilities and even the nature and extent of those responsibilities. Upon that ground alone we think sufficient has been said to indicate the legislative nature of the action taken Ibid.

by the Lieutenant Governor in council as set out in the order in council referred to.

Reference re Manitoba Language Rights, [1992] 1 SCR 212 [Reference re Manitoba Language Rights (No 2)].

Ibid at 216-17

Ibid at 223.

Ibid. The criteria identified in Manitoba Language Rights Reference (No 2), ibid, are applied in AUPE v Alberta (2002), 310 AR 240 (QB). In that case, the Court of Queen's Bench had to determine whether a deputy ministerial order was "of a legislative nature" to address the issue of whether the Minister had improperly sub-delegated its powers to the Deputy Minister under section 21(1) of the Interpretation Act. Applying the criteria set out in Manitoba Language Rights Reference (No 2), the Court concluded that the Deputy Ministerial Order did not fit within the general definition of "a rule of conduct, enacted by regulation-making authority pursuant to an Act of Parliament, which has the force of law for an undetermined number of persons" (para 76). In particular, Justice Murray states at para 79: "In my opinion, a declaration made by the Minister under s. 28(2) of the Hospitals Act is not an enactment by Government, nor is it subject to the approval of Government. It does not require positive action of Government 'to breathe life into it.' It is not tabled in the Legislative Assembly. It is not subordinate legislation and is not legislative in nature." See also para 83 "I am satisfied that an instrument such as D.M.O. 4/97 is not subordinate legislation or delegated legislation. Rather, it is simply an administrative function being performed by the Minister, or in this case, the Deputy Minister, as permitted under s. 
With respect to the form of the instrument, the Supreme Court of Canada determined that a sufficient connection between the legislature and the instrument in question is indicative of a legislative nature. ${ }^{140}$ This connection is established if a government enacts the instrument, if it is made subject to the approval of a government, or wherever "positive action of the Government is required to breathe life into [it]." ${ }^{141}$ Even if some instruments are not necessarily "Acts of the Legislature," they are determined to be legislative in form if they are tabled in the Legislative Assembly. ${ }^{142}$ With respect to the content and effect of the instrument, the Supreme Court of Canada indicated that the following criteria are indicative of a legislative nature: (i) the instrument sets a "rule of conduct," (ii) the instrument has the "force of law," and (iii) the instrument applies to "an undetermined number of persons."143 The Court further explains this point as follows:

\begin{abstract}
A "rule of conduct" can be described as a rule which sets norms or standards of conduct, which determine the manner in which rights are exercised and responsibilities are fulfilled. Pairing this with the phrase "force of law," the rule must be unilateral and have binding legal effect. Finally, it must also apply to "an undetermined number of persons," that is, it must be of general application rather than directed at specific individuals or situations. ${ }^{144}$
\end{abstract}

Even though the case law provides some criteria, there are "grey areas" and sometimes it may be difficult to distinguish whether an instrument is of an administrative or legislative nature. In addition, the Supreme Court of Canada indicated that these criteria are merely indicative and "[i]t is neither possible nor desirable to propose an ironclad test given the proliferation of instruments generated by contemporary governments." ${ }^{145}$ For this reason, the Alberta Legislative Counsel recommended that, if in doubt, the safest choice is to file the ministerial order with the Registrar. ${ }^{146}$

Ministerial orders issued under section 67 of REDA of an administrative nature presumably do not need to be filed or published in the Alberta Gazette and it remains uncertain whether they must be published elsewhere, such as on the Regulator's website. The value of transparency and accountability require that, regardless of their nature, directions

21(1) of the Interpretation Act.” Similar criteria are identified in Tsuu T'ina Nation v Alberta (Minister of Environment), 2008 ABQB 547, 96 Alta LR (4th) 65 [Tsuu T'ina Nation]. In that case, one of the remedies sought by the Tsuu T'ina Nation was a declaration to set aside the order in council that had approved the Water Management Plan for the South Saskatchewan River Basin. In deciding whether the order in council was of a legislative nature, the Alberta Court of Queen's Bench determined at para 61 that " $[\mathrm{t}] \mathrm{he}$ Court must consider the nature of the body enacting the order, the subject matter of the order, the application of the order, and the rights and responsibilities altered by the order.” The case was further appealed, 2010 ABCA 137, 482 AR 198, but the appellants on appeal withdrew their request to set aside the order in council approving the Plan and proceeded on other grounds.

Reference re Manitoba Language Rights (No 2), supra note 136 at 223-24 referring to Blaikie v Quebec (Attorney General), [1979] 2 SCR 1016 at 328-29.

Ibid.

Ibid at 224

Ibid at 224-25, 233. In identifying these criteria, the Court relies on the following definition of "regulation" to describe the criteria indicative of a "legislative nature": "[a] regulation is a rule of conduct, enacted by a regulation-making authority pursuant to an Act of Parliament, which has the force of law for an undetermined number of persons.” The Court notes that, even if in its original context the definition relates specifically to regulations, it provides assistance in developing a general definition of the phrase "of a legislative nature."

Ibid at 224-25.

Ibid at 223.

See Alberta, Alberta Justice, “A Guide to the Legislative Process - Acts and Regulations” (Edmonton: Alberta Justice, 2005) at 13-14, online: <https://www.solgps.alberta.ca/Publications1/Legislative\%20 process\%20manual.pdf $>$. 
under section 67 of REDA should be published on the Regulator's website and be easily accessible to the public. ${ }^{147}$ The public should be able to distinguish between a decision made by the Regulator and a decision made by the Alberta Government. If the Government interferes with a decision of the Regulator, it should be held politically responsible for it. Furthermore, when the direction involves substantial policy changes, interested parties should have a reasonable opportunity to comment on the proposed direction. ${ }^{148}$ Given that the Policy Management Office was established to act as an interface on policy issues between the Ministers and the Regulator, it could offer a forum for consultation on these proposed directions.

\section{G. THE APPROPRIATENESS OF DiRECTIONS}

The appropriateness of directions or the extent to which the Ministers should use them to ensure that the work of the Regulator is "consistent with the programs, policies and work of the Government" remains unclear under the current legislation. ${ }^{149}$ The concerns of the Opposition in the legislative debate, voiced by MLA Dr. Swan, that section 67(1)(b) "could be misused" or "give a false impression to some ministers that they can carry out far more intervention than is appropriate" seem to suggest that section 67 of $R E D A$ was not introduced in the statute to allow the Minister to routinely interfere with the work of the Regulator. ${ }^{150}$ However, in response to these concerns the Government House Leader firmly stated that the Regulator is only responsible for policy implementation and that policy-making is the role of the Alberta Government. ${ }^{151}$ Drawing a line is not easy and part of this debate depends on the meaning ascribed to the term policy. While there may be a general consensus that the Alberta Government is responsible for general policy-making, it is less clear that the Minister should also issue directions when policy-making entails technical issues. ${ }^{152}$

Executive directions are generally considered appropriate when a government foresees that the regulations of the agency "may touch sensitive issues of central policy planning."153 One of the main criticisms of the previous regime for reviewing energy projects in Alberta was that the broad mandate of the ERCB and the lack of guidance from the Government in certain areas created a policy vacuum that left the ERCB with no choice but to make its own policy. A pointed example was the controversy surrounding the decision of the ERCB to

See discussion in Part IV, below (directions to the British Columbia Utilities Commission and to the Ontario Energy Board are published on the website of the Commission and Board). See Nigel Bankes, “Constitutional Questions and the Alberta Energy Regulator” (24 October 2013), ABlawg (blog), online: <ablawg.ca/2013/10/24/constitutional-questions-and-the-alberta-energy-regulator> (commenting on the AER's policy in deciding what to publish on its website).

See e.g. Broadcasting Act, supra note 58, s 7(6) and Telecommunications Act, supra note 58, s 10(2) (requiring the Minister of Canadian Heritage to consult with the Commission before the Governor-inCouncil makes an order under the Broadcasting Act, and the Minister of Industry for consulting with the Commission before the Governor-in-Council makes an order under the Telecommunications Act. Both Acts require the Ministers to lay before each House of Parliament the proposed policy order and publish it by notice in the Canada Gazette inviting interested persons to make representations to the Ministers.)

REDA, supra note 8, s 67(1)(b).

See discussion in Part III.C, above and notes 71-70, supra.

Ibid.

See e.g. Telecommunications Act, supra note 58, s 8 (requiring that directions of the Governor-inCouncil be of general application on broad policy matters); Nuclear Safety and Control Act, supra note 58, s 19 (requiring that directions of the Governor-in-Council be of general application on broad policy matters); Broadcasting Act, supra note 58, s 7 (requiring that directions of the Governor-in-Council be of general application on broad policy matters). 
issue "Directive 074" that identified specific performance criteria for the management of tailing ponds. ${ }^{154}$ With the recent adoption of the Land-Use Framework ${ }^{155}$ and the Alberta Land Stewardship Act ${ }^{156}$ the Alberta Government is attempting to establish an innovative approach to managing the province's natural resources through integrated regional planning. This scheme is designed to ensure that natural resources are developed more efficiently while preserving the life-supporting capacity of air, water, land and biodiversity. ${ }^{157}$ Regional Plans established under $A L S A$ are "an expression of the public policy of the Government" and will be binding on all statutory decision-makers in Alberta. ${ }^{158}$ They will inform, guide, and direct uses of natural resources in order to achieve the desired outcome. ${ }^{159}$ This new scheme provides the Government with an important set of tools to establish policy on a number of important matters including cumulative impacts on air, land, and water. ${ }^{160}$ In addition, the Alberta Government established a new Policy Management Office for Natural Resources and Environment that will act as an interface between policy development and policy implementation. ${ }^{161}$ The Policy Management Office will report to the Department of Energy and ESRD, and will be responsible for ensuring that they develop coordinated policies as a collaborative effort, and that the policies are clearly communicated and understood by the Alberta Energy Regulator. ${ }^{162}$ While the Policy Management Office will initially focus only on the Regulator, its focus could also expand to other strategic policy initiatives in the future, including the Alberta Land Stewardship Act and the Land-Use Secretariat established under it. ${ }^{163}$ In this context, section 67 of REDA offers the legislative link that will allow the

In April 2008 the deaths of 500 ducks on a Syncrude tailing pond drew international attention to the ponds. The ERCB stated that mine operators had failed to meet their targets as promised in mine applications, but there was no sign from the Environment Department that they would address this gap. Therefore, the ERCB took the lead and in February 2009 issued a Ministerial Directive: Alberta Energy Regulator, "Directive 074: Tailings Performance Criteria and Requirements for Oil Sands Mining Schemes," (Calgary: Energy Resources Conservation Board, 3 February 2009) ["Directive 074"], online: $<$ www.aer.ca/documents/directives/Directive074.pdf $>$ identifying specific performance criteria for the proper management of tailing ponds. The Directive is a policy instrument, and the final version reflects feedback from government, industry and the public. The Directive established enforceable cleanup programs and deadlines for tailing pond construction, operations, closure and abandonment. The Directive also allows ERCB inspectors to take action if companies do not respect their commitments. On 13 March 2015, the Alberta Government suspended "Directive 074" and released the Tailings Management Framework for Mineable Athabasca Oil Sands (TMF). The TMF is a new government policy that provides direction to the Regulator on fluid tailings volumes and decreasing risks associated with the accumulation of fluid tailings on the landscape. See Alberta Energy Regulator, "Bulletin 201511: Directive 074: Tailings Performance Criteria and Requirements for Oil Sands Mining Schemes Suspended," by Kirk Bailey (AER, 13 March 2015), online: <www.aer.ca/documents/bulletins/Bulletin2015-11.pdf>. See also Technical Report, supra note 2 at 54-56; "New eco-Rules can shut oilsands," Edmonton Journal (26 June 2008), online: Canada.com < www.canada.com/edmontonjournal/news/ story.html?id=315bdd4d-24ad-4f6f-bcll-066823d55add $>$; for a further example of the tension existing between the Alberta Government and the ERCB, see discussion in supra note 35. LUF, supra note 6.

ALSA, supra note 6.

An integrated approach to natural resources promotes the coordinated development and management of water, land and related resources in order to make systematic and strategic decisions concerning appropriate land uses. For a detailed analysis of this type of approach, see Isobel W Heathcote, Integrated Watershed Management, Principles and Practice, 2nd ed (New Jersey: John Wiley \& Sons, 2009).

ALSA, supra note 6, ss 13(1), 15; REDA, supra note 8, s 20(1).

Ibid.

Cumulative effects are the impacts on the environment that result from the incremental impact of the action when added to other past, present, and reasonably foreseeable future actions regardless of what agency or person undertakes such other actions. See Government of Canada, Aboriginal Affairs and Northern Development Canada, Cumulative Impact Monitoring Program, online: Aboriginal Affairs and Northern Development Canada <www.aadnc-aandc.gc.ca/eng/1100100023828/1100100023830>.

The Policy Management Office is formally established within the Department of Energy. See Technical Report, supra note 2 at 55.

Ibid.

Ibid at 56. 
Government to formally coordinate the work of the new Alberta Energy Regulator within the broader provincial framework. Thus, if used carefully, directions to the Regulator might play an essential role particularly during this transitional phase and the shift to an integrated approach for the management of natural resources.

Some directions presumably will be based on the recommendations of the Policy Management Office according to the policy issues identified by the Regulator itself and communicated to the Policy Management Office. ${ }^{164}$ Directions could be used to clarify the Regulator's interpretation of its statutory mandate or clarify the general policies that should guide the Regulator in carrying out its mandate. Directions may also be an efficient way to address policy inconsistencies or gaps in the mandate of the Regulator. Section 2 of the $R E D A$, requires the Regulator to carry out its mandate with both "energy resource enactments" and with "specified enactments" as defined under REDA. ${ }^{165}$ Examination of these definitions reveals that the Regulator has several powers, duties, and functions assigned under a variety of acts and that the policies of these different sectors are not necessarily aligned. ${ }^{166}$ Therefore, directions could be used to promptly address these issues as they arise and avoid delays in the Regulator's decision-making.

Perhaps pending the implementation of additional Regional Plans, directions might be used to address policy issues concerning the approval of energy projects and other dispositions. At the moment, only the Lower Athabasca Region and South Saskatchewan have an approved Regional Plan under the ALSA, but clear thresholds for the environment have not been established. The North Saskatchewan Regional Plan is under development, while the other four regions (Upper Peace, Lower Peace, Red Deer, and Upper Athabasca) have not started the planning process yet. ${ }^{167}$ As more information on the status of these regions becomes available, directions could promptly set priorities and guidelines on certain activities, or limits and standards to land disturbance for certain areas.

See Alberta, Legislative Assembly, Alberta Hansard, 28th Leg, 1st Sess, No 54a at 2142.

REDA, supra note 8, s2(1). For the definition of "energy resource enactment" and "specified enactment" under REDA, see ss 1(1)(j), 1(1)(s). These enactments include the Coal Conservation Act, RSA 2000, c C-17; the Gas Resources Preservation Act, RSA 2000, c G-4; the Oil and Gas Conservation Act, RSA 2000, c O-6; the Pipeline Act, RSA 2000, c P-15; the EPEA, supra note 9; the Public Lands Act, supra note 9; the Water Act, supra note 9; and Part 8 of the Mines and Minerals Act, supra note 9.

Ibid. See also REDA, ibid note 8, s 2(2) (identifying without limitation the long list of the powers, duties and functions assigned to the Regulator including the following: applications under energy resource enactments in respect of pipelines, wells, processing plants, mines and other facilities and operations for the recovery and processing of energy resources; applications for the use of land in respect of energy resource activities, including approving energy resource activities on public land; applications and other matters under the EPEA in respect of energy resource activities; applications and other matters under the Water Act in respect of energy resource activities; to oversee the abandonment and closure of pipelines, wells, processing plants, mines and other facilities and operations in respect of energy resource activities at the end of their life cycle in accordance with energy resource enactments; to regulate the remediation and reclamation of pipelines, wells, processing plants, mines and other facilities and operations in respect of energy resource activities in accordance with the EPEA).

See Alberta Environment and Sustainable Development, "Land Use Alberta, Governance," online: Alberta Environment and Sustainable Development <https://www.landuse.alberta.ca/Governance/Pages/ default.aspx>. 
In 2013, the former Minister of the Department of Energy, Ken Hughes, stated that both the Policy Management Office and the Ministers will be allowed to give directions to the Regulator when necessary and that there will be regular discussions between the parties. ${ }^{168}$ In addition, he stated that the Policy Management Office will be responsible for, among other functions, monitoring the Regulator to ensure that water and other environmental permits will be properly issued to energy project proponents. ${ }^{169}$ Even though it is positive that, in response to several concerns, the Alberta Government has expressed its intention to ensure that energy development will be conducted in an environmentally responsible way, these statements are not completely reassuring. ${ }^{170}$ The new Regulator is not an agent of the Crown and the role of the Government is not to constantly influence its work. ${ }^{171}$ As previously discussed, the Regulator will be able to render decisions free of influence from political short-term goals, and thus make better decisions in the public interest, only if it is not subject to the direct control of the Government when exercising its duties and functions. Furthermore, depending on the perceived independence and impartiality of the Regulator in performing its functions, ministerial directions may be subject to litigation, which may itself compromise the vaunted goal of securing additional investments in the energy sector. Drawing a line is not easy and, to a certain extent, it is for the government of the day to make this decision. However, the Regulator was established at arm's length from the executive because its independence allows it to achieve its objective more readily than if it fell under the direct control of a ministry. Thus, ministerial directions should be issued cautiously or they may defeat the same reasons that prompted the Alberta Government to create the new Regulator.

\section{H. The Aboriginal Consultation Direction}

On 26 November 2013, the Minister of Energy issued to the Regulator the first direction under section 67 of REDA, namely the Ministerial Order 141/2013 (or the Aboriginal Consultation Direction). ${ }^{172}$ On 31 October 2014, the Minister of Energy and the Minister of Environment and Sustainable Resource Development (ESRD) issued a revised Aboriginal

See Sheila Pratt, "New Energy Regulator will Weaken Environmental Protection, Say Critics," Edmonton Journal (17 March 2013), online: <www.albertalandwonerscouncil.com/March\%2017,\% 202013,\%20Edmonton\%20Journal-New\%20energy\%20regulation\%20will\%20weaken\%20 environmental\%20protection.pdf>. In December 2013, Diana McQueen replaced Ken Hughes as Minister of Environment and Sustainable Resource Development. Ibid.

170 Several commentators have raised concerns that by taking over the functions previously administered by ESRD with respect to energy projects, environmental protection may be weakened. See e.g. Nigel Bankes, "Bill 2 and its implications for the jurisdiction of the Environmental Appeal Board" (9 November 2012), ABlawg (blog), online: <ablawg.ca/2012/11/09/bill-2-and-its-implications-for-thejurisdiction-of-the-Environmental-Appeal-Board>; Nigel Bankes, "A single window for the permitting of energy projects in Alberta: who will look out for the chickens?” (16 May 2011), ABlawg (blog), online: <ablawg.ca/2011/05/16/a-single-window-for-the-permitting-of-energy-projects-in-Alberta-whowill-look-out-for-the-chickens>; Cindy Chiasson, "Single energy regulator bill a poor deal for Alberta's environment” (1 November 2012), Environmental Law Centre (blog), online: ELC <environmentallaw centre.wordpress.com/2012/11/01/single-energy-regulator-bill-a-poor-deal-for-albertas-environment>. REDA, supra note $8, \mathrm{~s} 4$.

172 Alberta, Department of Energy, “Ministerial Order 141/2013”(Edmonton: Department of Energy, 2013) at 2, online: <www.energy.alberta.ca//Org/pdfs/MO141_2013woSignature.pdf>. For a commentary on this Ministerial Order, see Giorilyn Bruno \& Nigel Bankes, “The First Ministerial Direction to the Alberta Energy Regulator: The Aboriginal Consultation Direction” (24 April 2014), ABlawg (blog), online: <ablawg.ca/2014/04/24/the-first-ministerial-direction-to-the-alberta-energy-regulator-the aboriginal-consultation-direction $>$. 
Consultation Direction to the Regulator. ${ }^{173}$ This is the second Ministerial Order issued under section 67 of the REDA and it repeals the previous one.

The Regulator does not have the jurisdiction to assess the adequacy of Crown consultation. ${ }^{174}$ The current regulatory framework assigns this function to the Aboriginal Consultation Office (ACO), a new office established under the Aboriginal Relations Department. ${ }^{175}$ In this context, the Aboriginal Consultation Direction sets out a process that the Regulator must follow to ensure that it acts consistently with the decisions of the Government and to facilitate information exchange between the Regulator and the ACO. ${ }^{176}$ The Aboriginal Consultation Direction applies to applications to the Regulator in respect of energy resource activities under "specified enactments," as defined in the $R E D A .{ }^{177}$ The main purpose of this Direction is "to ensure that the AER considers and makes decisions in respect of energy applications in a manner that is consistent with the work of the Government of Alberta"178 in meeting its consultation obligations associated with the existing rights of Aboriginal people.

The Aboriginal Consultation Direction gives nine directions to the Regulator which are grouped under four subheadings: (1) Coordination; (2) Applications; (3) Decisions; and (4) Appeal and Reconsideration. Under "Coordination," the Aboriginal Consultation Direction requires the Regulator to create and maintain a consultation unit that will work with the Aboriginal Consultation Office (ACO). ${ }^{179}$ The Aboriginal Consultation Direction also requires the Regulator to collaborate with the ACO in establishing operating procedures that address how these two organizations will administer and coordinate their work. ${ }^{180}$ The Regulator is required to follow these procedures. ${ }^{181}$ Under "Applications," the Regulator must require all proponents to contact the ACO before submitting an energy application to the Regulator. ${ }^{182}$ Once submitted, the Regulator is to provide the ACO with certain

Alberta, Department of Energy, “Energy Ministerial Order 105/2014 Environment and Sustainable Resource Development Ministerial Order 53/2014” (Edmonton: Department of Energy, 31 October 2014) [Aboriginal Consultation Direction], online: <www.energy.gov.ab.ca/Org/pdfs/MOAboriginal ConsultationDirection.pdf $>$. For a commentary on this Ministerial Order, see Giorilyn Bruno \& Nigel Bankes, "A Revised Aboriginal Consultation Direction issued to the Alberta Energy Regulator" (8 December 2014) ABlawg (blog), online: <ablawg.ca/2014/12/08/a-revised-aboriginal-consultationdirection-issued-to-the-alberta-energy-regulator>. REDA, supra note 8, s 21.

The ACO is also responsible for all other aspects of First Nations consultation, including preconsultation assessment, management, and execution of the consultation process. See generally Alberta, Ministry of Aboriginal Relations, online: <www.aboriginal.alberta.ca/1.cfm>. Aboriginal Consultation Direction, supra note 173 at 2.

177 Ibid at 2. On 10 December 2014, the Assistant Deputy Minister of Aboriginal Relations (Alberta) and the Vice President of Government and Stakeholder Relations (AER) signed the "Joint Operating Procedures for First Nations Consultation on Energy Resource Activities,” (Edmonton: AER \& ACO, 10 June 2015) [“Joint Operating Procedures”], online: <www.aer.ca/documents/actregs/JointOperating Procedures.pdf $>$. The Agreement, which came into effect 2 March 2015 (the June 2015 revised version also sets out an application supplement requirement effective 1 July 2015), clarifies that the Aboriginal Consultation Direction, supra note 173 applies to applications made to the AER under the specified enactments. The Agreement at (iii) states: "The ministerial order issued on October 31, 2014 (Energy 105/2014 and Sustainable Resource Development 53/2014) and the Procedures apply only to applications made to the AER under the specified enactments, as defined by the Responsible Energy Development Act (i.e., Public Lands Act, Mines and Minerals Act (Part 8), Water Act, and the Environmental Protection and Enhancement Act), in respect of energy resource activities.” Aboriginal Consultation Direction, ibid at 2.

Ibid at 3.

Ibid. The “Joint Operating Procedures” have recently come into force: see discussion in supra note 177. Aboriginal Consultation Direction, ibid at 3.

Ibid. 
information with respect to the application. ${ }^{183}$ Assuming that consultation is required, the Regulator must ensure that proponents have included information about the potential adverse impact of the proposed project on existing rights and traditional uses by Aboriginal people in their application. ${ }^{184}$ Also, the Regulator is required to advise the ACO of any changes to the application, whether alternate dispute resolution involving Aboriginal people will be used, whether a hearing will be held on the application, and whether Aboriginal people will be included in the hearing process. ${ }^{185}$ Under "Decisions," the Aboriginal Consultation Direction requires the Regulator to seek advice from the ACO with respect to the adequacy of consultation and mitigation actions on potential adverse impacts on Aboriginal rights and traditional uses. ${ }^{186}$ The Regulator is also required to notify the ACO and provide the ACO with a copy of its decision and related reasons concerning the outcome of an energy application at the same time it notifies the proponent. ${ }^{187}$ Finally, under "Appeal and Reconsideration," the Regulator is required to provide the ACO with a copy of any application for regulatory appeal, reconsideration, or leave to appeal to the Court of Appeal filed by Aboriginal people. ${ }^{188}$

Some of the issues previously discussed may be analyzed in the context of the Aboriginal Consultation Direction. For instance, neither the first Ministerial Order nor the second one has been published in the Alberta Gazette. The first Ministerial Order 141/2013 was not even published on the Regulator's website; it was published on the website of the Department of Energy but only (and inexplicably) under the heading "Travel Reports." 189 This type of promulgation certainly raises concerns about the transparency of the process. Further, could the latest Aboriginal Consultation Direction be challenged on the ground that it was not formally published? Presumably, the Minister has to comply with the procedure prescribed under section 3 of the Regulations Act if the Aboriginal Consultation Direction is of a legislative nature. ${ }^{190}$ However, qualifying its nature is not straightforward. On one side, it may be argued that the Aboriginal Consultation Direction is of an administrative nature because it is directed at specific individuals (that is, the Regulator), and its overall thrust is to ensure a coordinated process and efficient information exchange between the Regulator and the ACO on energy applications that require Aboriginal consultation. ${ }^{191}$ In this case, the Minister would have no obligation to comply with the procedure prescribed under section 3 of the Regulations Act. On the other hand, other requirements of the Aboriginal Consultation Direction apply to the public and are concerned with setting standards of conduct. For instance, a proponent is required to contact the ACO before submitting an energy application and to include in the application certain documents and information. ${ }^{192}$

Ibid (in particular, the Direction requires that a copy of or access to the application be submitted to the Regulator, as well as a copy of any statement of concern, submission, evidence and information filed by any Aboriginal group concerning the application).

This requirement does not operate if the application concerns an activity that is deemed not to require consultation. This would happen in two instances: (1) the application concerns an activity that is listed under Appendix C of the Consultation Guidelines or (2) the application is accompanied by a preconsultation assessment of the ACO indicating that no consultation is required. See ibid at 4.

Ibid.

Ibid.

Ibid.

Ibid.

Supra note 172.

See discussion in Part III.F, above.

See Aboriginal Consultation Direction, supra note 173 at 3-4, Directions 1, 2, 5, 8. Ibid, Directions 4, 6. 
Since these requirements alter the exercise of rights and responsibilities of the public, it may be difficult to conclude that the Aboriginal Consultation Direction is purely of an administrative nature. In this case, it would have no effect because it was not issued in compliance with the procedure prescribed under section 3 of the Regulations Act.

Uncertainties arise also in the context of Direction 7, which requires the Regulator to seek advice on actions that may reduce the potential impacts on existing rights or on traditional uses of Aboriginal people. This direction states as follows:

7) Prior to making a decision in respect of an energy application for which First Nations consultation is required by the Consultation Guidelines or by the ACO, the AER shall request advice from the ACO

a) respecting whether Alberta has found consultation to have been adequate, adequate pending the outcome of the AER's process, or not required, and

b) on whether actions may be required to address potential adverse impacts on existing rights of aboriginal peoples as recognized and affirmed under Part II of the Constitution Act, 1982 or traditional uses as defined in the Consultation Policy. ${ }^{193}$

The Government's duty to consult may include the need to accommodate Aboriginal concerns. ${ }^{194}$ The standard of sufficient accommodation remains extremely vague but it may entail adjusting plans and projects to minimize impacts. Therefore, the rationale of Direction 7(b) seems to be to ensure that the duty to accommodate is adequately reflected in the regulatory approval process. However, to what extent can the ACO interfere with a decision of the Regulator concerning mitigating measures? Is the Regulator required to implement the measures recommended by the ACO? Does the Regulator maintain some level of discretion and the ultimate responsibility for the decision? The requirement that the Regulator must seek advice on mitigating measures seems to suggest that the ACO has oversight over the Regulator's decision. At the same time, Direction 7(b) does not require the Regulator to implement the advice received. Thus, presumably the Regulator maintains some level of discretion. Whether and to what extent the Regulator will in practice exercise discretion remains uncertain.

Lastly, it does not seem possible to identify the legal effects of the Aboriginal Consultation Direction on third parties or whether third parties have judicially enforceable rights. The reason is that it is first necessary to determine whether section 67 of the REDA generally allows legislative or administrative directions. But, as previously discussed, the answer to this issue is not clear. ${ }^{195}$

In conclusion, several issues remain unclear under section 67 of the REDA including the scope of the ministerial power, the legal status of directions issued under this provision, and the procedural requirements to issue directions. These legislative gaps create significant uncertainties in the current regulatory regime. 


\section{A Comparative Analysis With the BC Oil AND Gas Commission, THE BC UTILITIES COMMISSION, AND THE ONTARIO ENERGY BOARD}

Even though the power of the Minister under section 67 of $R E D A$ seems to be quite unique in Alberta, ${ }^{196}$ executive directions are not isolated in the tradition of Canadian administrative agencies. This part provides a comparative analysis of the BC Oil and Gas Commission, the BC Utilities Commission, and the Ontario Energy Board. The discussion is structured around the following questions:

- What is the scope of executive directions?

- Who has the power to issue directions?

- What type of procedure must be followed to issue directions?

- Has the power to issue directions been used?

\section{A. The BC OIL AND Gas Commission}

The BC Oil and Gas Commission is a single-window regulatory agency responsible for overseeing oil and gas operations in British Columbia, including exploration, development, pipeline transportation and reclamation. ${ }^{197}$ Some see it as the model on which REDA is based. The Commission performs regulatory functions and is considered to have a sufficient measure of decision-making authority to warrant being called arm's length or "independent." ${ }^{198}$ Regulatory responsibility is delegated to the Commission through the Oil and Gas Activities Act $^{199}$ and includes specified enactments including provisions of the Forest Act, ${ }^{200}$ the Heritage Conservation Act, ${ }^{201}$ the Land Act, ${ }^{202}$ the Environmental Management Act, ${ }^{203}$ and the Water Act. ${ }^{204}$

\section{COMMISSION SUBJECT TO DIRECTIONS}

The Commission may be subject to mandatory executive directions under section 25(1.1) of the Oil and Gas Activities Act. The provision states as follows:

(1) Subject to subsection (1.1), on application by a person under section 24 and after considering

A search (6 July 2015) using the term < “minister may by order” /p directions> in the Alberta CanLII data base returned 66 hits - none involving a tribunal like the Alberta Energy Regulator. The closest analogy was perhaps section 57.1 of $A L S A$ which allows the "Stewardship Minister may by order" issue directives that the secretariat and the stewardship commissioner must follow in carrying out their powers, duties and functions under this Act, the regulations and regional plans” [emphasis added]. The BC Oil and Gas Commission was originally established under the Oil and Gas Commission Act, SBC 1998, с 39. The Commission is now governed by the Oil and Gas Activities Act, SBC 2008, с 36, which repealed the Oil and Gas Commission Act effective 4 October 2010 (BC Reg 274/2010)). BC Oil and Gas Commission, “About Us” online: BC Oil and Gas Commission < www.bcogc.ca/aboutus>.

Ibid.

Forest Act, RSBC 1996, с 157.

Heritage Conservation Act, RSBC 1996, с 187.

Land Act, RSBC 1996, с 245.

Environmental Management Act, SBC 2003, c 53.

Water Act, RSBC 1996, с 483. 
(a) written submissions made under section 22(5), if any, and

(b) the government's environmental objectives, if any have been prescribed for the purposes of this section,

the commission may issue a permit to the person if the person meets the requirements prescribed for the purposes of this section.

(1.1) The Lieutenant Governor in Council, by regulation, may issue a direction to the commission with respect to the exercise of the commission's power under subsection (1), and the commission must comply with the direction despite any other provision of this Act, the regulations or an order made under this Act. ${ }^{205}$

\section{WHAT IS THE SCOPE OF EXECUTIVE DiRECTIONS UNDER THE OIL AND GAS ACTIVITIES ACT?}

By reference to section 25(1), executive directions may be issued with respect to the exercise of the Commission's power to issue permits and authorizations for oil and gas activities. ${ }^{206}$ An executive direction has the force of law and far-reaching implications since it trumps any other provision of the Oil and Gas Activities Act, the regulations or orders made under the Oil and Gas Activities Act. ${ }^{207}$

\section{WhO Has The POWER TO ISSUE DiReCTIONS TO THE BC OIL AND GAS COMMISSION?}

Section 25(1.1) of the Oil and Gas Activities Act, gives the power to issue directions to the Lieutenant Governor-in-Council.

\section{What Type of Procedure Must Be Followed to Issue Directions?}

The Lieutenant Governor-in-Council may give directions to the BC Oil and Gas Commission by way of regulation. ${ }^{208}$ Directions must be published in the British Columbia Gazette and have binding effect when deposited and published in the Gazette. ${ }^{209}$

\section{HAS THE POWER TO Issue DiRections BeEN USED?}

The Lieutenant-Governor-in-Council recently issued under section 25(1.1) of the Oil and Gas Activities Act, the first direction to the Commission. This direction prohibits the Commission from issuing a permit to a person to convert a liquified natural gas facility

Ibid.

Ibid; Interpretation Act, RSBC 1996, c 238, s 41(2).

Oil and Gas Activities Act, ibid, s 25(1.1).

See Interpretation Act, supra note 207, s 41; Regulations Act, RSBC 1996, c 402, ss 3, 5 . But see section 6 for publication exemptions (showing, for example, if publication in the Gazette is impracticable or unduly expensive due to the length of the regulation, or the regulation is or will be available to persons who are likely to be affected by it). 
pipeline into a pipeline for transporting oil or diluted bitumen. ${ }^{210}$ In 2011, the BC Government directed the Oil and Gas Commission not to issue permits under section 25 of the Oil and Gas Activities Act in relation to the exploration, development, and production of oil and gas resources in the Flathead watershed area. ${ }^{211}$ Even though this restriction on the powers of the Commission might have fallen under the scope of executive directions, in that instance, the BC Government instructed the Commission through the more formal and legitimate legislative process. ${ }^{212}$

\section{B. The BC UTILITIES COMMISSION}

The BC Utilities Commission is an independent regulatory agency primarily responsible for the regulation of British Columbia's natural gas and electricity utilities under the Utilities Commission Act. ${ }^{213}$ Additional responsibilities include the regulation of intra-provincial pipelines, electric power transmission facilities, and universal compulsory automobile insurance. ${ }^{214}$

\section{COMMISSION SUBJECT TO DIRECTIONS}

The BC Utilities Commission is subject to mandatory directions under section 3 of the Utilities Commission Act. The provision states as follows:

(1) Subject to subsection (3), the Lieutenant Governor in Council, by regulation, may issue a direction to the commission with respect to the exercise of the powers and the performance of the duties of the commission, including, without limitation, a direction requiring the commission to exercise a power or perform a duty, or to refrain from doing either, as specified in the regulation.

(2) The commission must comply with a direction issued under subsection (1), despite

(a) any other provision of

(i) this Act, except subsection (3) of this section, or

(ii) the regulations,

(a.1) any provision of the Clean Energy Act or the regulations under that Act, or

(b) any previous decision of the commission.

(3) The Lieutenant Governor in Council may not under subsection (1) specifically and expressly

Direction No 1 to the Oil and Gas Commission, BC Reg 1/2015.

Flathead Watershed Area Conservation Act, SBC 2011, c 20, s 3.

Ibid.

Utilities Commission Act, RSBC 1996, c 473.

Ibid. 
(a) declare an order or decision of the commission to be of no force or effect, or

(b) require the commission to rescind an order or a decision. ${ }^{215}$

\section{WHAT IS THE SCOPE OF EXECUTIVE DiRECTIONS} UNDER THE UTILITIES COMMISSION ACT?

Executive directions to the BC Utilities Commission may be issued with respect to the exercise of the powers and the performance of the duties of the commission. ${ }^{216}$ Similar to directions issued to the BC Oil and Gas Commission, a direction under section 3(2) of the Utilities Commission Act has far-reaching implications since it trumps any provision of the Utilities Commission Act and the Clean Energy Act or the regulations under these acts, as well as any previous decision of the commission. ${ }^{217}$

Section 3(3), sets an important substantive limit and prohibits the executive from declaring an order or decision of the commission to be of no force or effect, or requiring the commission to rescind an order or a decision. ${ }^{218}$

\section{Who Has The POWER TO IsSue Directions TO THE BC UTILITIES COMMISSION?}

Section 3 of the Utilities Commission Act gives the power to issue directions to the Lieutenant Governor-in-Council.

\section{What Type of Procedure Must Be Followed to Issue Directions?}

The Lieutenant Governor-in-Council may give directions by way of regulation. ${ }^{219}$ Executive directions must be published in the British Columbia Gazette, and have binding effects when deposited and published in the Gazette. ${ }^{220}$ As a matter of practice, directions are also published on the website of the BC Utilities Commission. ${ }^{221}$

\footnotetext{
215 Ibid, s 3.

Ibid.

Ibid.

Ibid, s 3(3). This restriction is consistent with the decision to eliminate Cabinet appeals in the province. See Janisch, supra note 30 at 82; Cabinet Appeals Abolition Act, SBC 1993, с 38. Utilities Commission Act, supra note 213, s 3.

See Regulations Act, supra note 209, ss 3-5, but see section 6 for publication exemptions (showing, for example, if publication in the Gazette is impracticable or unduly expensive due to the length of the regulation, or the regulation is or will be available to persons who are likely to be affected by it); Interpretation Act, supra note 207, s 41.

221 See British Columbia Utilities Commission, "Special Directions and Regulations to the British Columbia Utilities Commission,” online: British Columbia Utilities Commission <http://www.bcuc.com/Special
} Direction.aspx>. 


\section{Has the Power to Issue Directions Been Used?}

The Lieutenant Governor-in-Council has issued several directions requiring the Commission: (i) to set specific rates or to achieve specific outcomes when setting rates; ${ }^{222}$ (ii) to consider certain objectives before issuing a project certificate; ${ }^{223}$ (iii) to take into account specific factors when making decisions in the public interest; ${ }^{224}$ (iv) to exercise certain powers and functions in relation to the corporation generally; ${ }^{225}$ and (v) to not exercise certain powers. ${ }^{226}$

\section{THE ONTARIO ENERgy BOARD}

The Ontario Energy Board regulates the province's electricity and natural gas utilities in accordance with the Ontario Energy Board Act, $1998 .{ }^{227}$ Additional statutes that give jurisdiction to the Board are the Electricity Act, $1998,{ }^{228}$ the Municipal Franchises Act, ${ }^{229}$ the Oil, Gas and Salt Resources Act, ${ }^{230}$ the Assessment Act, ${ }^{231}$ and the Toronto District Heating Corporation Act. ${ }^{232}$

\section{BOARD SUBJECT TO DIRECTIONS}

The Board is subject to mandatory directions under more than eleven provisions of the Ontario Energy Board Act. ${ }^{233}$ Only two of the main provisions are reproduced here.

27. (1) The Minister may issue, and the Board shall implement, policy directives that have been approved by the Lieutenant Governor in Council concerning general policy and the objectives to be pursued by the Board.

(2) A policy directive issued under this section shall be published in The Ontario Gazette.

See Direction No 3 to the British Columbia Utilities Commission, BC Reg 105/2012; Special Direction No 10 to the British Columbia Utilities Commission, BC Reg 245/207 [Special Direction No 10]. Special Direction No 9 to the British Columbia Utilities Commission, BC Reg 157/2005, s 2.1. Special Direction No 10, supra note 222, s 4.

Special Direction IC2 to the British Columbia Utilities Commission, BC Reg 307/2004. This direction was challenged in BC Old Age Pensioners' Org v British Columbia (Minister of Public Safety \& Solicitor General), 2006 BCSC 257, [2006] BCJ No 330 (QL) (concerning the Lieutenant Governor-inCouncil issued Special Direction IC2 requiring the Insurance Corporation of British Columbia to transfer $\$ 530,000,000$ of capital allocated to its optional business to its basic insurance business, and further directed the British Columbia Utilities Commission to accept that transfer. The Petitioners alleged that Special Direction IC2 perverted the regulatory scheme in that it created a new regulatory chain of command that circumvented the statutory authority of the British Columbia Utilities Commission. The application was dismissed and the Court determined that the ICBC was an agent of government and all of its property and money was deemed to be property of government. As principal, the government, through the Lieutenant Governor-in-Council, was simply directing its agent ICBC in conduct of an aspect of its undertaking. The Special Direction IC2 did not turn the chain of command on its head, but it merely directed the British Columbia Utilities Commission to recognize and accept such direction). Direction to the British Columbia Utilities Commission Respecting the Iskut Extension Project, BC Reg $137 / 2013$.

Ontario Energy Board Act, 1998, SO 1998, c 15, Schedule B.

Electricity Act, 1998, SO 1998, c 15, Schedule A. The Electricity Act outlines the framework for Ontario's competitive electricity marketplace.

Municipal Franchises Act, RSO 1990, c M-55. The Municipal Franchises Act provides for the granting of a franchise to a natural gas distributor to provide natural gas service within a municipality. Oil, Gas and Salt Resources Act, RSO 1990, с P-12.

Assessment Act, RSO 1990, c A-31.

Toronto District Heating Corporation Act, 1998, SO 1998, с 15, Schedule C. See Ontario Energy Board Act, 1998, supra note 227, ss. 27-28.7. 
27.1 (1) The Minister may issue, and the Board shall implement, directives that have been approved by the Lieutenant Governor in Council that require the Board to take steps specified in the directives to promote energy conservation, energy efficiency, load management or the use of cleaner energy sources, including alternative and renewable energy sources.

(2) A directive issued under this section shall be published in The Ontario Gazette. ${ }^{234}$

\section{WHAT IS THE SCOPE OF EXECUTIVE DIRECTIONS UNDER THE ONTARIO ENERGY BOARD ACT?}

The initial 1998 version of the Ontario Energy Board Act contained only two provisions allowing executive directions with respect to (i) "general policy and the objectives to be pursued by the Board," 235 and (ii) "market rules made under section 32 of the Electricity Act, 1998 and existing or proposed licence conditions" in order to address market abuses. ${ }^{236}$ Subsequent amendments to the Ontario Energy Board Act in 2002, 2006, and 2009 have broadened the scope of directions. The Act currently allows directions for several purposes, including the following: (i) "to promote energy conservation, energy efficiency, load management or the use of cleaner energy sources, including alternative and renewable energy sources," 237 (ii) "to establish conservation and demand management targets to be met by distributors and other licensees,"238 (iii) to require the Board "to take such steps as are specified in the directive relating to the establishment, implementation or promotion of a smart grid for Ontario,"239 and (iv) in relation "to the government's smart metering initiative."240

In 2010, a further amendment to the Act introduced section 28.7 allowing executive directions "in relation to the marketing of gas and the retailing of electricity in Ontario."241 The length and scope of this provision is significant. In particular, subsection (3) of this provision allows the Minister to "require the Board to amend all licences so issued [under section 48 in respect of gas marketers or under section 57 in respect of retailers of electricity] or to amend specific licences of specified licensees."242 Subsection (4) provides a long and non-exclusive list of conditions that the Minister may require the Board to implement on licences already issued. ${ }^{243}$ Finally, subsection (6) allows directions requiring the Board to exercise audit, inspection, or investigating powers in certain circumstances. ${ }^{244}$

Ibid, ss 27-27.1.

Ibid, s 27(1).

Ibid, s 28 .

Ibid, s 27.1(1).

Ibid, s 27.2(1).

Ibid, s 28.5(1). Under section 28.5(2), a directive may also specify whether the Board is to hold a hearing and the circumstances under which a hearing may or may not be held.

Ibid, s 28.3(1). Under subsection 2 of this provision, the directives may also require the Board, in the manner specified in the directives, to amend conditions in licences issued by the Board, and provides a list of permissible conditions.

Ibid, ss 28.7.(1)

Ibid, s 28.7(3) [emphasis added].

Ibid, s 28.7(4).

Ibid, s 28.7(6). 


\section{WHO HAS THE POWER TO ISSUE DiRECTIONS TO THE ONTARIO ENERGY BOARD?}

The power to issue mandatory directions is assigned to the Minister of Energy subject to the approval of the Lieutenant Governor-in-Council. ${ }^{245}$

\section{What Type of Procedure Must Be Followed TO ISSUE DIRECTIONS?}

The Ontario Energy Board Act uses the term directive as the instrument by which directions are communicated to the Board. ${ }^{246}$ The term is not defined, but the Act requires that directives "shall be published in the Ontario Gazette."247 All directives are approved by Orders in Council and published on the OEB's website. ${ }^{248}$

\section{HAS THE POWER TO Issue DiRECTIONS BeEN USED?}

The Minister has used the direction power several times, principally to issue "conservation directives" under section 27.1 of the $A c t .{ }^{249}$ In a few instances, the Minister has also provided policy guidance through this instrument. ${ }^{250}$

The power to issue directives is given to the minister that is responsible for the administration of the Ontario Energy Board Act, 1998, ibid. At different times, that has been the Minister of Energy, Science and Technology, the Minister of Energy and Infrastructure and the Minister of Energy.

See Ontario Energy Board Act, 1998, ibid, ss 27, 28.7.

Ibid, s 27-27.2, 28.3, 28.5, 28.7.

See Ontario Energy Board, “Directives Issued to the OEB by the Minister of Energy," online: Ontario Energy Board < www.ontarioenergyboard.ca/OEB/Industry/Regulatory+Proceedings/Directives+Issued +to+the+OEB>.

See the following directives issued under section 27.1 of the Ontario Energy Board Act: directive Jun 4-03 (requiring the Board to consult with stakeholders to identify and review options for the delivery of demand side management and demand response activities within the electricity sector, and to report back to the Minister of Energy with the Board's analysis and recommendations); directive Jun 23-04 (requiring the Board to develop and provide to the Minister of Energy an implementation plan for the achievement of the Government's smart meter targets, as well as in relation to the need for and potential effectiveness of non-commodity time of use rate structures); directive Aug 10-06 (requiring the Board to dispense with compliance by Enbridge Gas Distribution Inc. and Union Gas Limited with sections of their respective undertakings given to the Lieutenant Governor in Council, such that these gas utilities can provide services related to the promotion of conservation, electricity management and the promotion of cleaner energy sources); directive Sep 8-09 (requiring the Board to dispense with compliance by Enbridge Gas Distribution Inc. and Union Gas Limited with sections of their respective undertakings given to the Lieutenant Governor in Council, such that these gas utilities can own and operate certain generation facilities as well as assets required in respect of the provision of energy conservation services); directive Mar 31-10 (requiring the Board to establish electricity conservation and demand management (CDM) targets to be met by licensed electricity distributors and to issue a code pertaining to CDM). Ibid, s 27.1 .

See Directive Jun 7-00 (requiring that the Board give primacy to the objective of protecting the interests of consumers in setting electricity distribution rates, and that the Board invite representations from the council of the municipal corporation(s) within the service area of an electricity distributor before making an order setting that distributor's distribution rates) and Directive May 16-07 (requiring the Board to implement such measures as the Board considers necessary to address the issue of stray voltage as it affects the farm sector). Ibid. 
D. TABle Of Results

\begin{tabular}{|c|c|c|c|}
\hline & $\begin{array}{l}\text { BC Oil and Gas } \\
\text { Commission }\end{array}$ & $\begin{array}{l}\text { BC Utilities } \\
\text { Commission }\end{array}$ & Ontario Energy Board \\
\hline Authorizing provision & $\begin{array}{l}\text { Oil and Gas Activities } \\
\text { Act, s. } 25\end{array}$ & $\begin{array}{l}\text { Utilities Commission } \\
\text { Act, s. } 3\end{array}$ & $\begin{array}{l}\text { Ontario Energy Board } \\
\text { Act, ss. 27, 27.1, 27.2, } \\
\text { 28, 28.1, 28.2, 28.3, } \\
28.4,28.5,28.6,28.7\end{array}$ \\
\hline $\begin{array}{l}\text { Authority to issue } \\
\text { mandatory directions }\end{array}$ & $\begin{array}{l}\text { Lieutenant Governor-in- } \\
\text { Council }\end{array}$ & $\begin{array}{l}\text { Lieutenant Governor-in- } \\
\text { Council }\end{array}$ & $\begin{array}{l}\text { Minister of Energy } \\
\text { subject to the approval } \\
\text { of the Lieutenant } \\
\text { Governor-in-Council }\end{array}$ \\
\hline Scope of directions & $\begin{array}{l}\text { Power of the } \\
\text { Commission to issue oil } \\
\text { and gas permits }\end{array}$ & $\begin{array}{l}\text { Powers and performance } \\
\text { of duties of the } \\
\text { Commission }\end{array}$ & $\begin{array}{l}\text { The scope includes but } \\
\text { is not limited to the } \\
\text { following: general } \\
\text { policy and objectives to } \\
\text { be pursued by the } \\
\text { Board; market rules; } \\
\text { promoting energy } \\
\text { conservation and } \\
\text { efficiency }\end{array}$ \\
\hline $\begin{array}{l}\text { Instrument by which } \\
\text { the Authority may } \\
\text { issue directions }\end{array}$ & Regulation & Regulation & Directive \\
\hline $\begin{array}{l}\text { Has the power to } \\
\text { issue directions been } \\
\text { used? }\end{array}$ & Yes & Yes & Yes \\
\hline $\begin{array}{l}\text { Are directions subject } \\
\text { to mandatory } \\
\text { publication in the } \\
\text { relevant Gazette? }\end{array}$ & Yes & Yes & Yes \\
\hline $\begin{array}{l}\text { Are directions } \\
\text { published on the } \\
\text { Commission or } \\
\text { Board's website? }\end{array}$ & No & Yes & Yes \\
\hline
\end{tabular}




\section{ConClusion}

Section 67 of $R E D A$ was justified as an attempt to reconcile the need of the executive to delegate decision-making to the Regulator, while preserving oversight of the Regulator's decision-making to ensure accountability. It follows that balancing these two conflicting interests is essential to achieve good governance.

The current legislation leaves open significant issues under section 67 of REDA, including the scope, the legal status of directions, and the procedural requirements to issue them. ${ }^{251}$ In addition, while this article addressed some aspects of the relationship between section 67 of REDA and section 10 of APAGA, future research should analyze this topic more extensively. ${ }^{252}$ These gaps create uncertainties in the current regulatory regime and exacerbate the concern that ministerial directions will be improperly used.

The comparative analysis with British Columbia and Ontario suggests that section 67 of $R E D A$ could be improved with respect to three aspects. First, the statutory power to give directions to the Regulator could be either assigned directly to the Lieutenant Governor-inCouncil (as in the case of the BC Oil and Gas Commission and BC Utilities Commission) or require the approval of the Lieutenant Governor-in-Council (as in the case of the Ontario Energy Board). ${ }^{253}$ This approach may be perceived as more legitimate and may protect the Ministers of Energy and ESRD from direct conflicts with the stakeholders and the general public. ${ }^{254}$ Furthermore, this approach may ensure that directions reflect broad policy of the Alberta Government and not the policy of a single department. ${ }^{255}$ Second, section 67 of REDA could prescribe that orders be published in the Alberta Gazette. This requirement would define the manner in which the executive should communicate with the Regulator and may clarify that issuing policy directions is a legislative act in nature and effect. As we have seen, directions to the BC Oil and Gas Commission and Utilities Commission must be formally issued and have the status of regulation. ${ }^{256}$ Similarly, and despite being referred to as "directives," the procedure to issue directions to the Ontario Energy Board resembles the legislative process; thus, they also seem to have the status of delegated legislation. ${ }^{257}$ This formal approach avoids the difficulties concerning directions of an administrative nature which may be binding on the agency but unenforceable in the courts. ${ }^{258}$ In addition, this approach enhances transparency and may protect the agency from undue political interference. ${ }^{259}$ The third lesson that we could learn from the comparative analysis concerns transparency. Transparency requires the information to be easily retrievable and not buried in bureaucracy or, as in the case of Ministerial Order 141/2013, under the "Travel Reports" of the Minister of Energy. ${ }^{260}$ The public should be able to distinguish between a decision made by the Regulator and a decision made by the Alberta Government. If the Government interferes with a decision of the Regulator it should be held politically responsible for it. The

\footnotetext{
See discussion in Part III, above.

See discussion in Part III.E, above.

See discussion in Part IV, above.

See discussion in Part III.B, above.

Ibid

See discussion in Part IV, above.

Ibid.

See discussion in Part III.D, above.

Ibid.

See discussion in Part III.H, above.
} 
executive directions issued to the BC Utilities Commission and the Ontario Energy Board offer a pointed example of transparent information. Not only are they published on the agency's website but they are also easily retrievable by the public. ${ }^{261}$

The comparative analysis seems to be less useful when attempting to draw conclusions as to the appropriateness of directions or the extent to which the executive should use section 67 of $R E D A$ to ensure that "the work of the Regulator is consistent with the programs, policies and work of the [Alberta] Government." 262 The different structure and mandate of both the BC Utilities Commission and the Ontario Energy Board do not allow a meaningful comparison. With respect to the BC Oil and Gas Commission, the Lieutenant Governor-inCouncil has only issued one direction under section 25(1.1) of the Oil and Gas Activities Act. Reasons may include that the Lieutenant Governor-in-Council has a broad power to make regulations under other provisions of the Act. For instance, the Lieutenant Governor-inCouncil has the power to make regulations concerning the "policies and procedures to be followed by the Commission in conducting its affairs, exercising its powers and discretion carrying out its functions and duties and discharging its responsibilities."263 The Lieutenant Governor-in-Council may make regulations concerning "actions that a permit holder and a person carrying out an oil and gas activity must take or refrain from taking to protect or effectively manage the environment." 264 The Lieutenant Governor-in-Council may make regulations to prohibit the carrying out of an oil and gas activity. ${ }^{265}$ Last, the Lieutenant Governor-in-Council may make regulations to exempt "a person, class of persons, place, thing, transaction or activity" from a provision of the Oil and Gas Activities Act or the regulations, as well as to restrict the Commission's authority to provide for exemptions in certain matters. ${ }^{266}$ An executive direction issued to the BC Oil and Gas Commission under section 25(1.1) would trump these regulations in case of inconsistencies. ${ }^{267}$ However, the legislative scheme seems to imply that executive directions should be issued as a last resort given that the Lieutenant Governor-in-Council has a broad power to issue regulations under other provisions. This may partly explain why the power under section 25(1.1) of the Oil and Gas Activities Act has been used only once.

By contrast, in Alberta the circumstances are different. The reasons that lead to the enactment of REDA include the desire of the Alberta Government to shift to an integrated management system able to address the cumulative impacts of natural resource development. ${ }^{268}$ Section 67 of REDA was introduced in the Act to facilitate this shift and allow the Government to ensure that the work of the Regulator does not compromise the broader policy framework set out by the Government. ${ }^{269}$ Thus, we should not be surprised if section 67 of $R E D A$ ends up playing a significant role, particularly during this transitional phase.

\footnotetext{
261 See discussion in Part IV, above.

REDA, supra note 8, s 67(1)(b).

See Oil and Gas Activities Act, supra note 197, s 95(1).

Ibid, s 103(1).

Ibid, s 97.

Ibid, s 98(1).

See discussion in Part IV.A, above.

See Technical Report, supra note 2 at 54-58.

See discussion in Part III.C, above.
} 
As we keep searching for the right balance between independence and accountability, we may accept the political reality that the Regulator is not absolutely independent and that the executive has a role in its governance. However, we should also keep in mind that delegation of statutory authority to arm's length regulatory bodies typically occurs when it would be ineffective or inappropriate for the executive to exercise those functions directly. Thirty years ago, the Law Reform Commission of Canada perhaps gave the best general advice. Executive directions should be used as a means of formal guidance when the intervention of the legislature would be inefficient, and following a process that is open to public involvement and transparent. ${ }^{270}$ 